\title{
The Effect of Explicit Convection on Climate Change in the West African Monsoon and Central West African Sahel Rainfallo
}

\author{
LaWrence S. Jackson, ${ }^{\mathrm{a}}$ John H. Marsham, ${ }^{\mathrm{a}}$ Douglas J. PARker, ${ }^{\mathrm{a}}$ Declan L. Finney, ${ }^{\mathrm{a}}$ \\ Rory G. J. FitzPATRICK, ${ }^{a}$ DAVID P. ROWEll, ${ }^{\mathrm{b}}$ RACHEl A. STRATTON, ${ }^{\mathrm{b}}$ AND SimON TUCKER ${ }^{\mathrm{b}}$ \\ ${ }^{\text {a }}$ School of Earth and Environment, University of Leeds, Leeds, United Kingdom \\ ${ }^{\mathrm{b}}$ Met Office, Exeter, United Kingdom
}

(Manuscript received 31 March 2021, in final form 28 September 2021)

\begin{abstract}
The West African monsoon (WAM) is the dominant feature of West African climate providing the majority of annual rainfall. Projections of future rainfall over the West African Sahel are deeply uncertain, with a key reason likely to be moist convection, which is typically parameterized in global climate models. Here, we use a pan-African convection-permitting simulation (CP4), alongside a parameterized convection simulation (P25), to determine the key processes that underpin the effect of explicit convection on the climate change of the central West African Sahel $\left(12^{\circ}-17^{\circ} \mathrm{N}\right.$, $\left.8^{\circ} \mathrm{W}-2^{\circ} \mathrm{E}\right)$. In current climate, $\mathrm{CP} 4$ affects WAM processes on multiple scales compared to P25. There are differences in the diurnal cycles of rainfall, moisture convergence, and atmospheric humidity. There are upscale impacts: the WAM penetrates farther north, there is greater humidity over the northern Sahel and the Saharan heat low regions, the subtropical subsidence rate over the Sahara is weaker, and ascent within the tropical rain belt is deeper. Under climate change, the WAM shifts northward and Hadley circulation weakens in P25 and CP4. The differences between P25 and CP4 persist, however, underpinned by process differences at the diurnal scale and large scale. Mean rainfall increases $17.1 \%$ in CP4 compared to $6.7 \%$ in P25 and there is greater weakening in tropical ascent and subtropical subsidence in CP4. These findings show the limitations of parameterized convection and demonstrate the value that explicit convection simulations can provide to climate modelers and climate policy decision makers.
\end{abstract}

KEYWORDS: Convection; Monsoons; Climate change

\section{Introduction}

The Sahel region of West Africa (herein $12^{\circ}-17^{\circ} \mathrm{N}$ ) relies on seasonal rainfall from the West African monsoon (WAM) to meet the needs of its growing population and its rain-fed agriculture (Boko et al. 2007; Busby et al. 2014; Niang et al. 2014). It is a semiarid region with a sharp transition from the tropical climate to the south to hot dry desert to the north. The social and economic well-being of the people of West Africa is sensitive to extremes, and variations in the WAM (Cornforth 2012). Climate change projections, important for sustainable adaptation planning, remain deeply uncertain for the West African Sahel. Projections show that West Africa will warm during the twenty-first century, yet they fail to find consensus for the magnitude or sign of future changes in rainfall (Christensen et al. 2013; Rowell et al. 2016; Dosio et al. 2019) and the CMIP5 ensemble changes over West Africa are assessed at low to medium confidence (Niang et al. 2014).

The WAM is dynamically linked to the Hadley circulation (Nicholson 2009; Seth et al. 2019; Biasutti 2019). Both the tropical rain belt over West Africa and the Sahel rainfall have large-scale drivers in SST gradients and tropical teleconnections (Sheen et al. 2017) and in the Saharan heat low (SHL)

Supplemental information related to this paper is available at the Journals Online website: https://doi.org/10.1175/JCLI-D-210258.s1.

Corresponding author: Lawrence S. Jackson, 1.s.jackson@leeds. ac.uk
(Biasutti et al. 2009; Dixon et al. 2018). The WAM involves a June-September reversal of the low-level northeasterly winds with the southwesterly monsoon driven by the temperature gradient between the Gulf of Guinea coastline and its northern interior (Fontaine and Philippon 2000). The northern extent of the monsoon is marked by the intertropical discontinuity (ITD), also referred to as the intertropical front (ITF), where the relatively cool moist southwesterly monsoon converges with the hot dry northeasterly trade wind (the Harmattan). The low-level monsoon flow has a pronounced diurnal cycle in which the winds are attenuated during the afternoon by strong dry convection in the boundary layer and subsequently accelerate during the evening and overnight resulting in a nocturnal low-level jet (Parker et al. 2005b; Lothon et al. 2008; Vizy and Cook 2018).

The seasonal development of the SHL between the Atlas Mountains (to the north) and Hoggar Mountains (to the east) plays a key role in establishing the low-level meridional pressure gradient across West Africa and strengthens the lowlevel transport of moisture across the region (Lavaysse et al. 2009). The SHL forms as a result of localized intense heating of the surface during daytime (Johnson 2003). The overlying atmosphere is heated by absorption of longwave (LW) radiation emitted by the land surface, dry convection, and atmospheric absorption of shortwave (SW) radiation. Changes in temperature are amplified by Saharan water vapor-temperature feedback (Evan et al. 2015), a process through which the WAM and the SHL are coupled (Marsham et al. 2016; Shekhar and Boos 2017). Heating results in localized convergence, low-level cyclonic circulation and low pressure near the 
surface, and divergence at $\sim 700 \mathrm{hPa}$ (Nicholson 2009; GarciaCarreras et al. 2015). A shallow, dry northerly circulation transports Saharan air at $\sim 700 \mathrm{hPa}$ toward the region of deep convection to the south (Rowell 2003; Thorncroft et al. 2011). The low-level temperature gradient between the Gulf of Guinea and the southern Sahara drives midlevel easterly winds, including the African easterly jet (AEJ), which are approximately geostrophic and maintain vertical wind shear in accordance with the thermal wind balance (Cook 1999; Parker et al. 2005a).

Sahel rainfall occurs between the deep convection of the tropical rain belt to the south and the ITD to the north (Nicholson 2009). The rainfall is frequently associated with mesoscale convective systems (MCSs) (Fink et al. 2006), which predominantly initiate during late afternoon and early evening and propagate westward (Pearson et al. 2010). MCSs reinforce the northward propagation of moisture and sustain the initiation of moist convection (Provod et al. 2016; Trzeciak et al. 2017). The WAM promotes atmospheric conditions favorable for MCSs such as the supply of moisture from lowlevel southwesterly winds (Bock et al. 2011) and the vertical wind shear between the low levels $(\sim 925 \mathrm{hPa})$ and midlevels $(\sim 600 \mathrm{hPa})$ (Dudhia et al. 1987; Houze 2004; Parker et al. 2005a; Taylor et al. 2017), and the AEJ (Mohr and Thorncroft 2006). Indeed, both a low-level flux of moisture and wind shear are fundamental for the organization of convection in regions where MCSs are prevalent such as the central United States, southeast South America, and west equatorial Africa (Zipser et al. 2006; Jackson et al. 2009).

Projections of greenhouse gas-induced climate change over West Africa are highly uncertain (Christensen et al. 2013). Different climate models project different signs and magnitudes of change and it is difficult to conclusively dismiss apparent outlier models (Rowell et al. 2016). Nevertheless, some robust responses to climate change over West Africa have been identified. In the north of the region, the Sahara Desert is likely to experience amplified warming of near-surface temperatures associated with its dry environment and strong water vapor feedbacks (desert amplification) (Cook and Vizy 2015; Zhou et al. 2015; Zhou 2016; Wei et al. 2017). Amplified warming over the Sahara and northern Sahel drives an increase in the near-surface temperature gradient (Vizy et al. 2013; Raj et al. 2019) although there are large intermodel variations in the projected change in meridional temperature gradient across West Africa (Rowell et al. 2021).

The parameterization of moist convection in climate models is one of the largest sources of model uncertainty (Sherwood et al. 2014) that is not ameliorated in most downscaled simulations using regional climate models over West Africa (Dosio et al. 2019). Convection-permitting models (CPMs), in which convection is explicitly resolved at high spatial resolutions, produce improved simulations of rainfall (Prein et al. 2015). Rainfall in CPMs at subdaily time scales is less frequent, more intense, and occurs later in the day than in equivalent parameterized convection models (PCMs) and provides a closer match to observations and satellite data (Pearson et al. 2014; Stratton et al. 2018; Woodhams et al. 2018; Berthou et al. 2019b; Stein et al. 2019; Vizy and Cook 2019). Simulations using CPMs demonstrate improved coupling between convection and convergence (Birch et al. 2014a; Finney et al. 2020) and better capture land surface interactions in convective initiation (Taylor et al. 2013). CPMs give improved upscale impacts to continental-scale circulations (Marsham et al. 2013; Birch et al. 2014b; Hart et al. 2018; Jackson et al. 2020).

The Future Climate for Africa (FCFA) research program has developed a pan-Africa scale CPM and produced highresolution convection-permitting simulations (CP4) of current and future climate over Africa (Stratton et al. 2018; Kendon et al. 2019; Senior et al. 2021). The CP4 simulation of current climate for West Africa provides improvements over an equivalent parameterized convection simulation (P25). The mature phase of the monsoon is better captured as are the diurnal cycle of rainfall and wet and dry spells (Berthou et al. $2019 b)$. There is also improvement in the representation of MCSs (Crook et al. 2019) and westward storm propagation in the latitude band $5^{\circ}-15^{\circ} \mathrm{N}$ is better captured (Stratton et al. 2018; Crook et al. 2019). The CP4 simulation of future climate over West Africa shows a decrease in the frequency of rainy days and an increase in the intensity of rainfall (Berthou et al. 2019a) with the increase in extreme rainfall intensity driven primarily by the increase in atmospheric moisture (Fitzpatrick et al. 2020), although there is evidence that increasing windshear may add to this (Taylor et al. 2017; Bickle et al. 2021). The intensity of subdaily rainfall is projected to increase at rates exceeding the rate of increase in moisture according to the Clausius-Clapeyron relationship (Kendon et al. 2019).

In this study, we investigate the mechanisms that underlie the differences between climate change projections from parameterized and explicit convection. We use the CP4 simulations in which Berthou et al. (2019a) and Kendon et al. (2019) have shown that projections of future climate change are sensitive to the representation of convection in climate models. We focus on the central West African Sahel $\left(12^{\circ}-17^{\circ} \mathrm{N}, 8^{\circ} \mathrm{W}-2^{\circ} \mathrm{E}\right)$, a region where we find rainfall change is particularly sensitive to the representation of convection. First, we aim to identify the key processes that differ between parameterized and explicit convection in simulations of the current climate. Second, we aim to determine if these differences persist in the future climate and identify the key processes that differ between parameterized and explicit convection under climate change.

A description of the data and climate model simulations is presented in section 2. Our results are presented in section 3 . We start by assessing how well P25 and CP4 represent the WAM system in current climate compared to reanalysis (section 3a). We then compare the climate change results for P25 and CP4 (section 3b). In section 3c we present our analysis of processes that underlie the monsoon changes in P25 and CP4 which includes surface radiation [section 3c(1)], pressure gradients and low-level meridional winds [section $3 \mathrm{c}(2)$ ], moisture budget diurnal cycle [section $3 c(3)$ ], large-scale circulations [sections $3 c(4)$ and $3 c(5)$ ], and wind shear [section $3 c(6)]$. Finally, discussion and conclusions follow in section 4. 


\section{Climate model, data, and methods}

\section{a. Regional climate model configurations}

Two RCM configurations, one with parameterized convection (P25) and one with explicit convection permitted (CP4), were run independently for a limited-area domain (Stratton et al. 2018). The domain extended from $45^{\circ} \mathrm{S}$ to $40^{\circ} \mathrm{N}$ and from $25^{\circ} \mathrm{W}$ to $56^{\circ} \mathrm{E}$ to include all of Africa and to locate the boundaries away from the coast of Africa. Both RCM configurations used the Met Office Unified Model (UM), which is a nonhydrostatic model with a semi-implicit, semi-Lagrangian dynamical core. Both configurations were based on Even Newer Dynamics for General Atmospheric Modeling of the Environment (ENDGame) dynamics (Wood et al. 2014). Lateral boundary conditions for both configurations were driven by one-way nesting (Davies 2014) in an unnudged global N512 AMIP simulation with 85 vertical levels using the Global Atmosphere/Land 7.0 (GA7/GL7) configuration of the UM (Walters et al. 2019), hereinafter referred to as G25. A 2-month spinup period was applied to the RCM configurations and a 10-yr spinup period was used offline for soil moisture (Stratton et al. 2018). To aid realism of the simulations, a pan-Africa uniform sandy soil type was used in both RCM configurations to mitigate the occurrence of spurious convective initiations triggered by small-scale variability in soil type (De Kauwe et al. 2013).

\section{1) PARAMETERIZED CONVECTION SIMULATION (P25)}

The parameterized convection RCM configuration used a horizontal grid spacing of $\sim 25-\mathrm{km}$ latitude and $\sim 39-\mathrm{km}$ longitude at the equator, the same as the G25 configuration, and 63 vertical levels up to $41 \mathrm{~km}$. Parameterized convection was based on the Gregory-Rowntree mass flux scheme (Gregory and Rowntree 1990) with several enhancements including allowance for downdrafts, convective momentum transport, and a closure based on convectively available potential energy (Walters et al. 2017). The prognostic cloud scheme PC2 (Wilson et al. 2008) was used in the P25 configuration (and the G25 configuration).

\section{2) CONVECTION-PERMitTing SIMULATION (CP4)}

The convection-permitting RCM configuration used a horizontal grid spacing of $\sim 4.5-\mathrm{km}$ latitude and longitude at the equator and 80 vertical levels up to $38.5 \mathrm{~km}$. Convection was represented explicitly using the model dynamics although it only partly resolved deep convection on a $4.5-\mathrm{km}$ grid resolution and cannot resolve smaller-scale congestus or shallow convection (Stratton et al. 2018). Previous studies using explicit convection in the UM, however, yielded an improved spatial distribution of rainfall and an improved diurnal cycle compared to TRMM (Birch et al. 2014b) and these improvements were largely a result of explicitly resolving convection rather than finer model resolution (Pearson et al. 2014) and were achieved despite $4.5-\mathrm{km}$ grid resolution being within the "gray zone" for resolution of convection (Field et al. 2017). This has since been confirmed for CP4 (Berthou et al. 2019b).
There are other notable differences between the P25 and CP4 simulations (Stratton et al. 2018). The large-scale cloud scheme used in CP4 is described by Smith (1990) and has been used in previous convection-permitting versions of the UM. Following Lock et al. (2000), CP4 included stochastic perturbations in the subcloud layer of cumulus-capped boundary layers to improve the triggering of resolved convection. A moisture conservation scheme was used in CP4 (Aranami et al. 2015), which reduced mean and extreme precipitation across West Africa (Stratton et al. 2018). To facilitate comparison of the CP4 and P25 simulations, data from the CP4 simulation were regridded using area weighting to the P25 horizontal grid resolution.

\section{3) Current Climate simulations}

The G25 and RCM simulations were forced with sea surface temperatures (SSTs) derived from the Reynolds dataset of daily high-resolution blended analyzes for SST on a regular spatial grid of $0.25^{\circ}$ resolution (Reynolds et al. 2007). The G25 simulation was run for years 1988-2010. The current climate (CC) RCM simulations were run for 10 years (1997-2006). Atmospheric greenhouse gas (GHG) concentrations had fixed global values that were updated annually. Aerosol concentrations in the RCMs were based on climatologies from an earlier version of the climate model that used the CLASSIC aerosol scheme (Walters et al. 2019). Aerosols in G25 were interactive and used the U.K. Chemistry and Aerosols (UKCA) scheme. The RCM simulations used GHG concentrations based on those for the G25 simulation and interpolated to their regional model grids. The initial conditions for the RCM atmospheres were taken from the G25 simulation on 1 January 1997. For further details of the G25 and RCM simulations, including tables that list the differences between the RCM simulations, see Stratton et al. (2018).

\section{4) FUTURE CLIMATE SIMULATIONS}

The future climate (FC) simulations were run for a period of 10 years (2095-2104) using the same setup used for the CC simulations except for changes to the GHG concentrations and the lateral boundary conditions (Kendon et al. 2019). The GHG concentrations were taken from year 2100 in projections of representative concentration pathway 8.5 (RCP8.5) (Moss et al. 2010). The SST changes were taken from the climatological average SST change between 1975-2005 and 2085-2115 in a HadGEM2-ES RCP8.5 simulation. These SST changes were calculated by grid cell for each calendar month, interpolated in space and time, and added to the daily Reynolds SST climatology that was used in the CC simulations. The same aerosol and ozone climatologies were used in the $\mathrm{CC}$ and FC simulations.

\section{b. Spatial and seasonal averaging/aggregation}

We focus on the West Africa region $\left(5^{\circ}-35^{\circ} \mathrm{N}, 20^{\circ} \mathrm{W}-20^{\circ} \mathrm{E}\right)$ within the pan-Africa domain of the simulations. Within this West Africa region, we focus on a meridional transect $\left(8^{\circ} \mathrm{W}-2^{\circ} \mathrm{E}\right)$ and, in particular, on the central West African Sahel $\left(12^{\circ}-17^{\circ} \mathrm{N}\right)$. This meridional transect was chosen to 
focus on the meridional flow in the central West African Sahel, excluding the far western Sahel where projected rainfall changes differ markedly from changes farther east (Niang et al. 2014), and also excluding regions to the east where the Hoggar mountains affect the near-surface environment (e.g., the low-level monsoon flow, temperature, and radiation fluxes). Henceforth, all subsequent references to the Sahel refer to this central West African Sahel region. The results presented are July-August means averaged over the 10 years of the simulations. The July-August period was used because the seasonal WAM is well established (Nicholson 2013) and the SHL is broadly stationary before commencing its southward migration in September (Lavaysse et al. 2009).

\section{c. Reanalysis data}

ERA5 data were used (Hersbach et al. 2019). The data are monthly means on pressure levels for geopotential and for meridional and zonal winds. ERA5 was chosen because of its relatively high spatial resolution, a $0.25^{\circ} \times 0.25^{\circ}$ latitude-longitude grid, which is close to that of P25. ERA5 is a relatively new reanalysis dataset so ERA-Interim data (Dee et al. 2011) were also used. ERA-Interim has previously been used in studies of the SHL. For example, Cook and Vizy (2015) found ERA-Interim to be self-consistent and appropriate for study of the processes associated with the SHL. The ERA-Interim data are 6-hourly (averaged to monthly means) with a T255 spectral horizontal resolution $(\sim 79 \mathrm{~km})$.

\section{d. Statistical significance}

A bootstrap resampling method was used to test the statistical significance of differences between two simulations (e.g., between P25 and CP4 or between current climate and future climate). The data from each simulation were paired by year because they are based on the same driving model and consequently not independent. A total of 1000 random samples, with replacement, of the 10 July-August means were taken. The tests are two-tailed with a 5\% significance level.

\section{Results}

\section{a. Saharan heat low: Evaluation of current climate simulations}

We evaluate the simulation of the SHL in the RCMs by comparison against ERA5 (Fig. 1). In the reanalysis, the SHL is located north of the Sahel between the Atlas and Hoggar mountains with the region of greatest thickness adjacent to the Hoggar Mountains $\sim 24^{\circ} \mathrm{N}$. Moving south and west there are steep gradients in thickness. The gradient is approximately zonally oriented across West Africa. The simulated SHL in the RCMs closely resembles the reanalysis. A key difference is that the position of the heat low in CP4 more closely matches reanalysis, whereas in P25 the heat low is located $\sim 3^{\circ}$ latitude farther south than in ERA5.

In ERA5, the height of the 925-hPa geopotential surface has a zonal minimum at $\sim 22^{\circ} \mathrm{N}$ (the monsoon trough). There is a cyclonic circulation about the trough, which is a region of convergence of the southwesterly monsoon and the northeasterly Harmattan winds. Moving south from the monsoon trough, the meridional gradient in the geopotential height (GPH) extends to the Gulf of Guinea and provides a pressure gradient that drives the flow of moist monsoon air toward the Sahel. The monsoon trough is located farther south in P25 and CP4 compared to ERA5 (more so in P25), which affects the flow of winds around the trough and over north Sahel.

In ERA5, the height of the 700-hPa geopotential surface rises to a maximum in the north of the heat low region, adjacent to the Atlas Mountains, and has a domelike shape with a meridional gradient in height moving south toward the Gulf of Guinea. There is an anticyclonic circulation about the peak in GPH, which contributes to prevailing easterly and northeasterly midlevel winds across West Africa. The three-dimensional circulations about the SHL (925-700 hPa) are, therefore, tilted toward the north with increasing height. The large-scale pattern in GPH and winds is reproduced in P25 and CP4. Both RCMs locate the peak in GPH at $700 \mathrm{hPa}$ close to the location of the peak in ERA5 although it is slightly too far north in P25.

In summary, P25 and CP4 simulated SHL climatologies that are similar to ERA5. We also repeated the comparison of P25 and CP4 against ERA-Interim and found substantially similar results (not shown).

\section{b. Climate change}

In this section we present climate change results for P25 and CP4. In section $3 b(1)$, we focus on spatial patterns over West Africa. In section $3 b(2)$, we focus on a meridional transect from the Gulf of Guinea coast to the Sahara desert $\left(5^{\circ}-30^{\circ} \mathrm{N}\right)$ averaged over longitudes $8^{\circ} \mathrm{W}-2^{\circ} \mathrm{E}$.

\section{1) WEST AFRICA REGION}

Mean July-August near surface land temperature increases by $6.3^{\circ} \mathrm{C}(\mathrm{P} 25)$ and $6.2^{\circ} \mathrm{C}(\mathrm{CP} 4)\left(5^{\circ}-30^{\circ} \mathrm{N}, 20^{\circ} \mathrm{W}-10^{\circ} \mathrm{E}\right.$; Figs. 2a,b). Warming is greatest over the Sahara Desert where the climate is hot and dry and there is sparse vegetation. Amplified warming over the Sahara Desert has been observed in recent climate change (Cook and Vizy 2015; Zhou et al. 2015; Zhou 2016; Wei et al. 2017) and projected in future climate change (Vizy et al. 2013, Raj et al. 2019).

The thickness (and temperature) of 925-700-hPa air increases across West Africa under climate change (Figs. 2c,d) increasing the intensity of the SHL. Warming is greatest to the north and the SHL shifts northward. The change in location of the SHL is accompanied by a northward shift in the GPH trough at $925 \mathrm{hPa}$ although there is relatively little change in the location of peak in GPH at $700 \mathrm{hPa}$ (not shown). The monsoon trough in CP4 is farther north than in P25 in both current and future climates.

Total column water (TCW) increases strongly in future climate (Figs. 3a,b). In both P25 and CP4 the largest increases occur in the region of the tropical rain belt $\left(\sim 10^{\circ}-15^{\circ} \mathrm{N}\right)$ with greater increases in the east of the region than in the west likely associated with strengthened low-level cyclonic circulation. The largest increases in TCW occur in P25 although the 

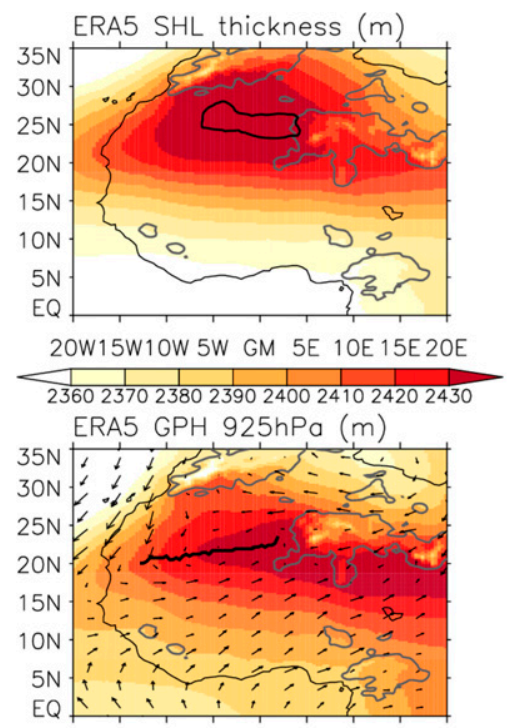

20W15W10W 5W GM 5E 10E 15E20E

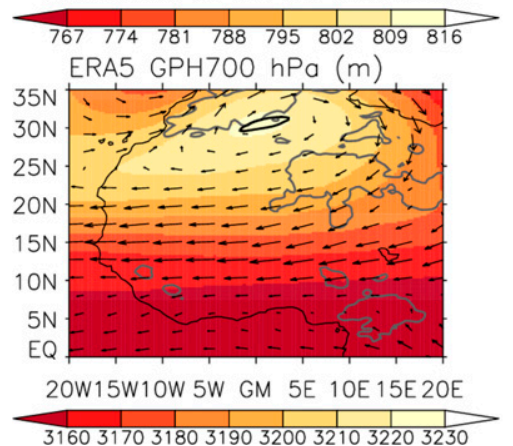

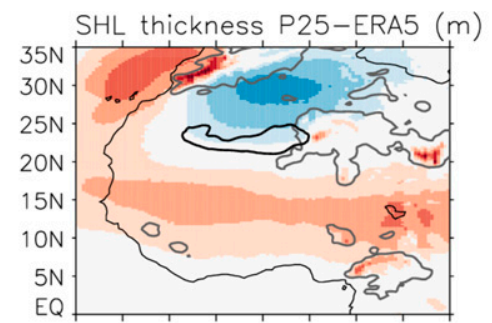
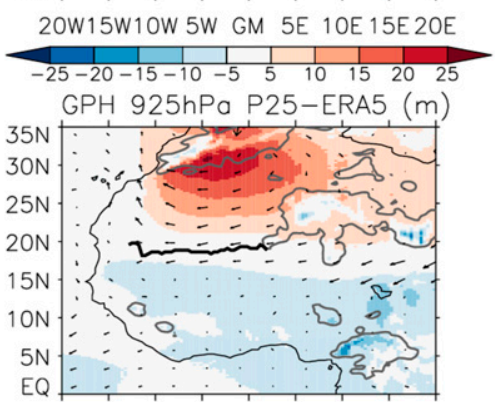

20W15W10W 5W GM 5E 10E 15E 20E
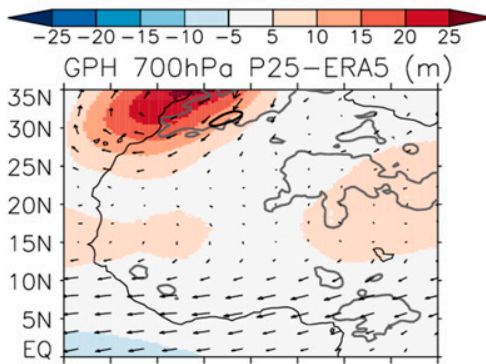

20W15W10W 5W GM 5E 10E 15E20E

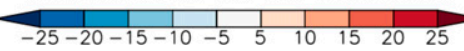

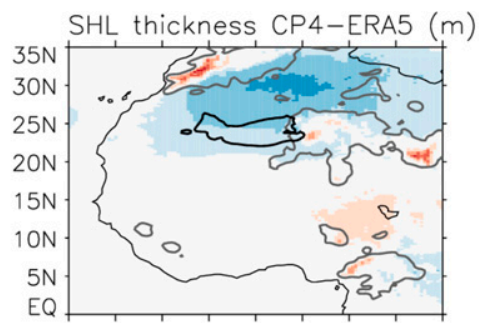

20W15W10W 5W GM 5E 10E 15E 20E
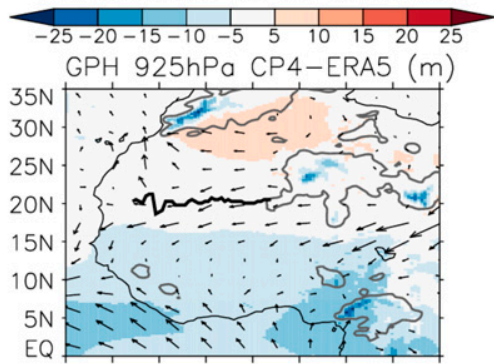

20W15W10W 5W GM 5E 10E 15E 20E
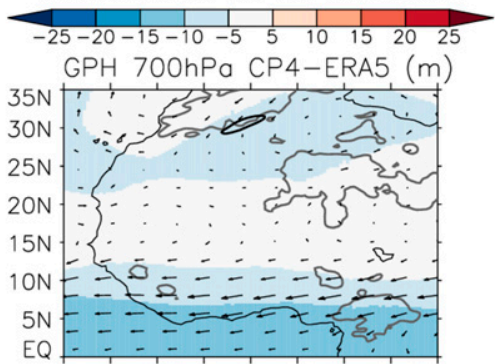

20W15W10W 5W GM 5E 10E 15E 20E

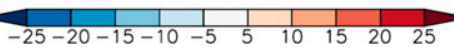

FIG. 1. July-August (top) thickness for the 925-700-hPa layer, (middle) GPH at $925 \mathrm{hPa}$, and (bottom) GPH at $700 \mathrm{hPa}$. (left) ERA5, (center) the difference between P25 and ERA5, and (right) the difference between CP4 and ERA5. Winds at 925 and 700 hPa are shown by the vectors in the middle and bottom rows, respectively. In the top row, the regional maximum thickness is enclosed within the black contour. In the middle row, the trough in GPH at $925 \mathrm{hPa}$ is marked by the black line. In the bottom row, the peak GPH at $700 \mathrm{hPa}$ is enclosed within the black contour. Gray contour lines represent $600-\mathrm{m}$ orographic elevation.

increase in TCW to the north of the Sahel region is larger in CP4.

P25 and CP4 project similar geographic patterns of rainfall change over West Africa $\left(5^{\circ}-30^{\circ} \mathrm{N}, 20^{\circ} \mathrm{W}-10^{\circ} \mathrm{E}\right)$ with spatial mean increases of $+8.5 \%$ and $+3.8 \%$ respectively (Figs. $3 \mathrm{c}, \mathrm{d})$. The spatial distribution of rainfall shifts eastward with a decrease in rainfall over the western Sahel and an increase in rainfall over central and eastern Sahel in line with the changes in TCW. The spatial distribution of rainfall shifts northward between $10^{\circ} \mathrm{W}$ and $10^{\circ} \mathrm{E}$, with a decrease along the Guinea coast and increases farther north. Using a strong climate change scenario (RCP8.5), the sign of change is statistically significant over much of the Sahel but not where the sign of change transitions, nor generally farther south, due to natural variability.

\section{2) MERIDIONAL TRANSECT}

The meridional transects in rainfall reveals marked differences between CP4 and P25, particularly over the Sahel region (Figs. 4a,b). In current climate, the rain belt is positioned farther north in $\mathrm{CP} 4$ and there is greater rainfall over most of the Sahel region. Under climate change, P25 and CP4 project increased rainfall north of $8^{\circ} \mathrm{N}$ and significant increases in the vicinity of the main rain belt $\left(9^{\circ}-13^{\circ} \mathrm{N}\right)$. There are greater differences between P25 and CP4 over the Sahel region, with a greater northward shift in the rain belt in CP4. The increase in rainfall over the Sahel is statistically significant in $\mathrm{CP} 4$ but not in $\mathrm{P} 25$, and the climate change in rainfall is markedly greater in $\mathrm{CP} 4(+17.1 \%$ in $\mathrm{CP} 4$ and $+6.7 \%$ in P25 with the difference significant at the $1 \%$ significance level).

The meridional temperature gradients in P25 and CP4 differ over the northern Sahel and the southern Sahara regions despite having similar temperatures at the Guinea coast and in the Sahara region (Fig. 4c). The meridional gradient in CP4 is weaker than P25 across the northern Sahel and stronger in the region of the SHL $\left(\sim 22^{\circ} \mathrm{N}\right)$. Under climate change, warming is greatest to the north of the region, producing an increase in the meridional temperature gradient in both P25 

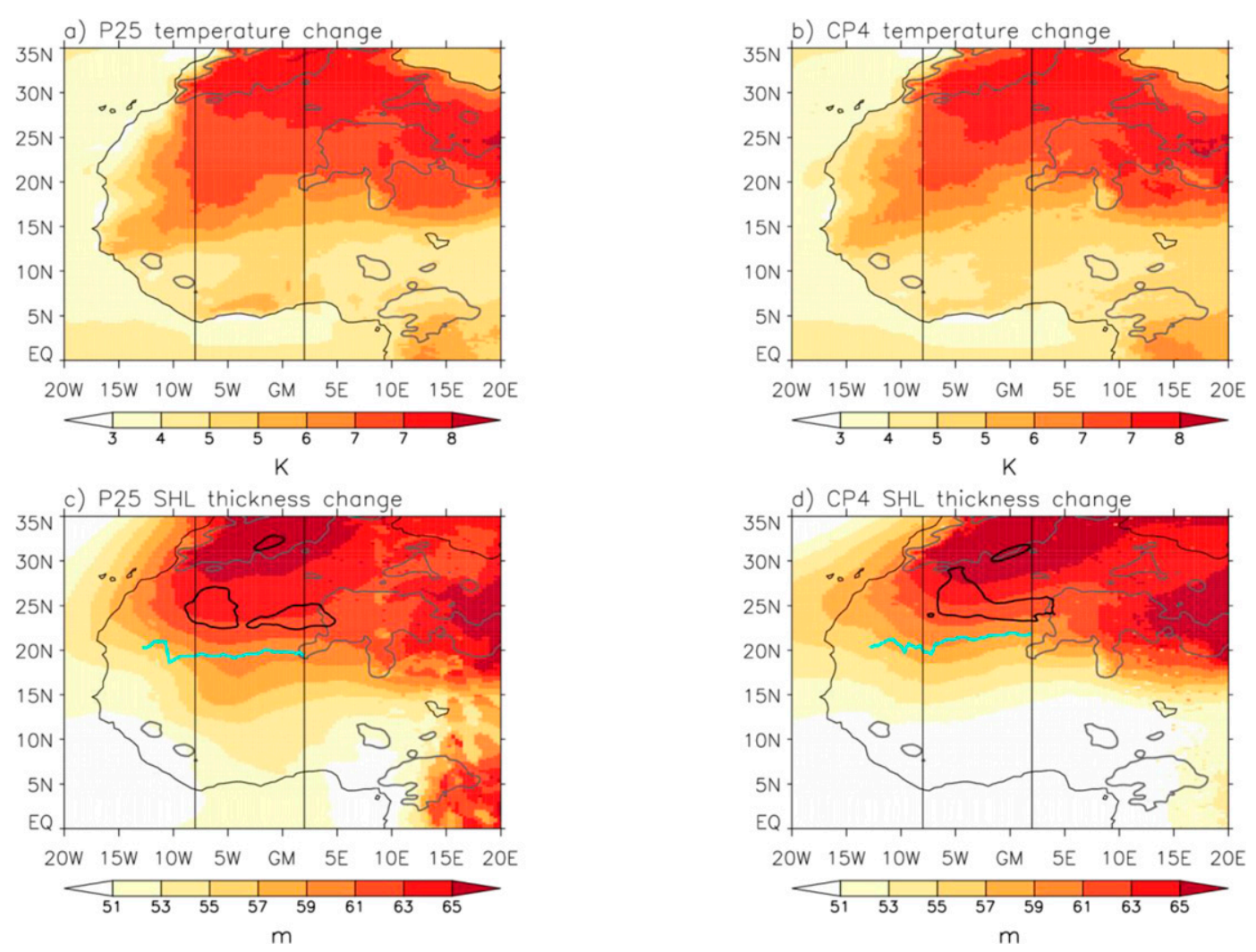

FIG. 2. Climate changes in July-August (a),(b) near-surface temperature $(\sim 1.5 \mathrm{~m})$ and (c),(d) SHL thickness $(925-700 \mathrm{hPa})$. The change for both variables is statistically significant at the $5 \%$ significance level in all grid cells. In (c) and (d), the trough in $\mathrm{GPH}$ at $925 \mathrm{hPa}$ in future climate is represented by the cyan line, and the location of the anticyclonic circulation at $700 \mathrm{hPa}$ is indicated by the black contour line showing $1 \mathrm{~m} \mathrm{~s}^{-1}$ wind speeds at $700 \mathrm{hPa}$. Gray contour lines represent $600-\mathrm{m}$ orographic elevation. The black vertical lines mark the meridional transect used in Fig. 4 and thereafter (bounded by longitudes $8^{\circ} \mathrm{W}$ and $2^{\circ} \mathrm{E}$ ).

and CP4. From the Guinea coast to $22^{\circ} \mathrm{N}$, the changes in temperature differ significantly between P25 and CP4 (Fig. 4d). CP4 warms less than P25 to the south, which results in a greater increase in its meridional temperature gradient.

$\mathrm{GPH}$ at $925 \mathrm{hPa}$ decreases from the Guinea coast to the southern Sahara. The trough in GPH is farther north in CP4 than P25 (Fig. 4e) and the meridional gradient in GPH is stronger in P25 than in CP4 both equatorward and poleward of the trough. Under climate change, GPH in both P25 and CP4 increases such that, south of the trough, the meridional gradient strengthens and the trough shifts northward (Fig. 4f). The increase in GPH is significantly greater in CP4 throughout the meridional transect, which suggests differences between P25 and CP4 in changes to dynamics at scales larger than considered here. The maximum in $925-700-\mathrm{hPa}$ thickness marks the position of the SHL over this meridional transect (Fig. 4g). It is located farther north in CP4 than P25 and shifts farther north in both P25 and CP4 under climate change (Fig. 4h).

In current climate, the meridional distributions of TCW (Fig. 5a) and specific humidity (Fig. 5c) differ between P25 and CP4. In P25, humidity is greater south of $\sim 17^{\circ} \mathrm{N}$ whereas CP4 has substantially greater specific humidity north of the
Sahel in the SHL region. Under climate change, specific humidity increases throughout the transect (Figs. 5b,d) and the differences between P25 and CP4 are magnified. P25 has a greater increase in humidity in the region of the rain belt $\left(\sim 10^{\circ}-12^{\circ} \mathrm{N}\right)$.

Over the Sahel, meridional and zonal 925-hPa wind speeds are stronger in P25 than CP4 whereas over the southern Sahara region zonal wind speeds are stronger in CP4. Winds from the southwest penetrate farther north in CP4 than P25 consistent with the relative locations of the troughs in GPH (Fig. 5e). Under climate change, both meridional and zonal wind speeds strengthen, and the southwesterly winds penetrate farther north in both P25 and CP4. Over the Sahel, the westerly wind component strengthens much more in CP4 than P25.

In summary, there are marked differences between the current climate states of $\mathrm{P} 25$ and $\mathrm{CP} 4$. Meridional gradients in temperature and GPH at $925 \mathrm{hPa}$ are weaker in CP4 than P25 yet monsoon winds penetrate farther north. Humidity is greater in CP4 over the north Sahel and southern Sahara regions. Climate change acts to reinforce these differences between $\mathrm{P} 25$ and $\mathrm{CP} 4$ and brings strengthened gradients in temperature and GPH across West Africa and a northward 

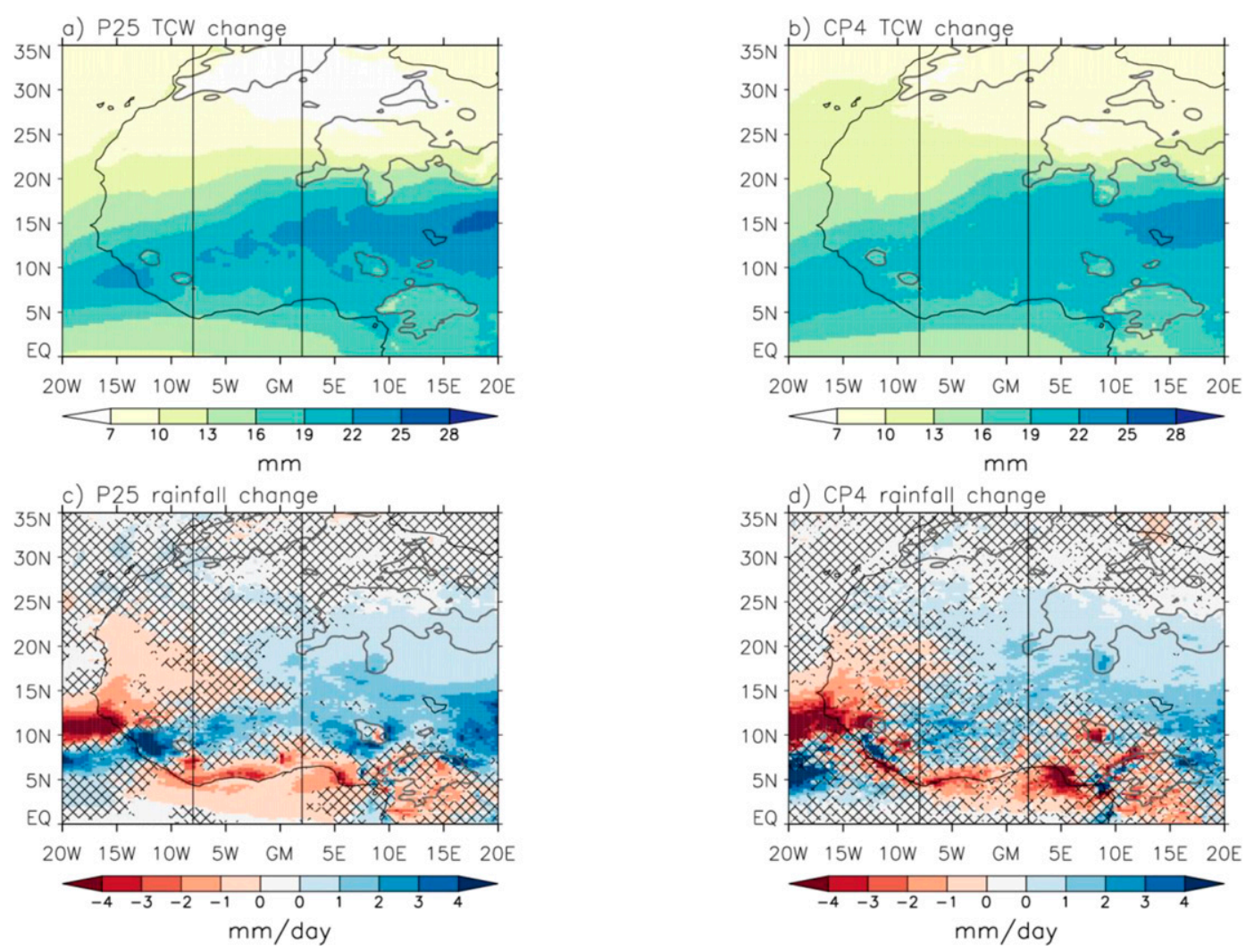

FIG. 3. Climate changes in July-August (a),(b) TCW and (c),(d) rainfall. Changes not statistically significant at the $5 \%$ significance level are hatched. Gray contour lines represent $600-\mathrm{m}$ orographic elevation. The black vertical lines mark the meridional transect used in Fig. 4 and thereafter (bounded by longitudes $8^{\circ} \mathrm{W}$ and $2^{\circ} \mathrm{E}$ ).

shift in the monsoon in both models. The most prominent difference between P25 and CP4 under climate change is the increase in Sahel rainfall, which is 2.6 times greater in CP4 than $\mathrm{P} 25$.

\section{c. Analysis of WAM/SHL processes}

In this section we examine processes that drive or interact with the WAM. We analyze their response to climate change and assess their contribution to the contrasting rainfall changes in P25 and CP4 over the Sahel region. We begin with the surface radiation changes, which are strongly driven by the greenhouse gas forcing [section $3 c(1)]$. Next, we examine the meridional winds [section $3 \mathrm{c}(2)]$. We then proceed to examine the moisture budget response at the diurnal time scale [section $3 c(3)$ ] and larger-scale dynamical responses [section 3c(4)-(6)].

\section{1) SURFACE RADIATION CHANGES}

Over the Sahel region, the cloud radiative effect (CRE) on surface SW radiation is similar in P25 and CP4 (Fig. 6a). South of the Sahel, and particularly over the Gulf of Guinea, the CRE on surface SW radiation is greater in CP4 than P25. This is associated with greater concentrations of cloud liquid water below 4-km altitude in CP4 than $\mathrm{P} 25$. To the north over the Sahara region, CP4 has smaller concentrations of cloud liquid water than P25 (particularly at 5-7-km altitude) and a weaker CRE on surface SW radiation. Under climate change, the CRE on surface SW radiation weakens, which results in a small increase in surface SW radiation in both $\mathrm{P} 25$ and CP4 with little to no meridional gradient in this radiation flux (Fig. 6b). Clear-sky surface SW radiation increases from south to north in both P25 and CP4 in an inverse relationship with the meridional decrease in TCW (Fig. 6c). Clear-sky surface SW radiation is greater in $\mathrm{P} 25$ than $\mathrm{CP} 4$ and is likely associated with the vertical distribution of humidity; CP4 has greater humidity than P25 at higher altitudes. Under climate change, there is a decrease in clear-sky surface SW radiation (Fig. 6d) associated with increased atmospheric absorption of nearinfrared radiation because of the increase in humidity (Fig. 5). Under climate change, the changes in surface SW radiation are small compared to changes in downwelling LW radiation (below) and the meridional gradients in the SW radiation flux changes are weak.

Differences in low and midlevel cloud liquid water concentrations between $\mathrm{P} 25$ and $\mathrm{CP} 4$ have the opposite effect on the CRE for surface $\mathrm{LW}$ radiation than surface SW radiation (Fig. 6e). Under climate change, there is a broadly uniform decrease in the meridional CRE for surface $\mathrm{LW}$ radiation (Fig. 6f) in both P25 and CP4. The magnitude of the change 

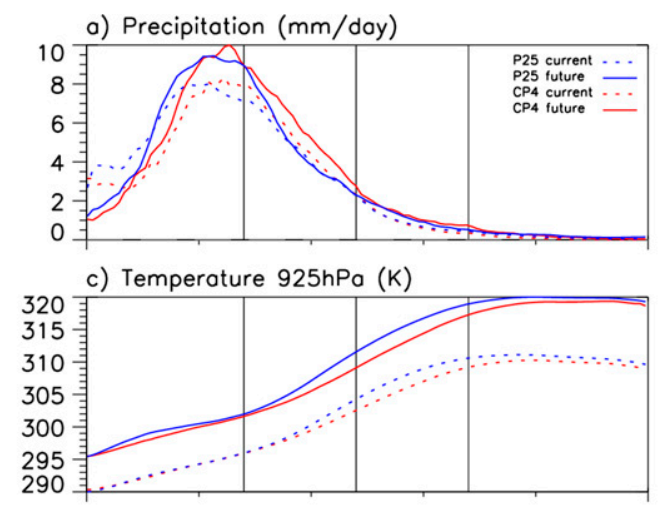

e) $\mathrm{GPH} 925 \mathrm{hPo}(\mathrm{m})$
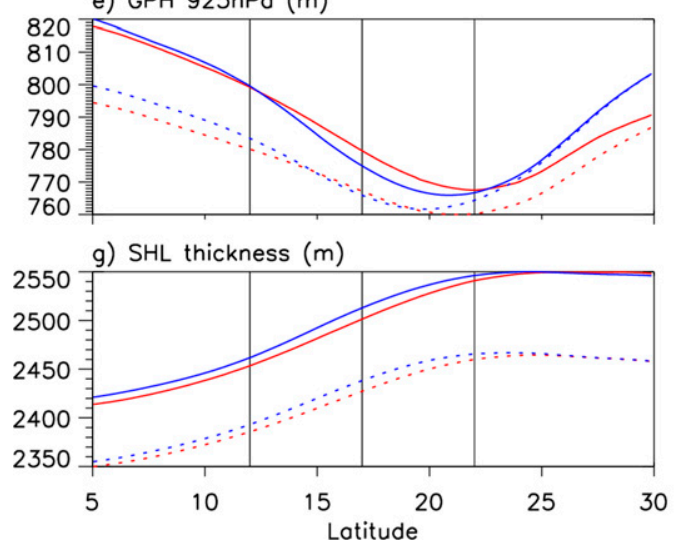

b) Change in precipitation ( $\mathrm{mm} /$ doy)

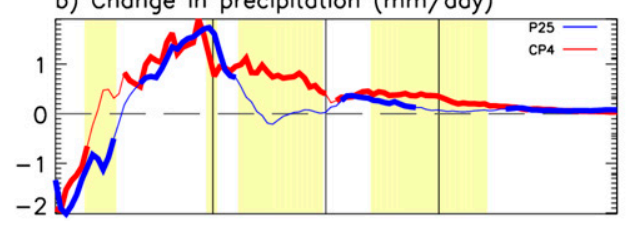

d) Change in temperature $925 \mathrm{hPa}(\mathrm{K})$
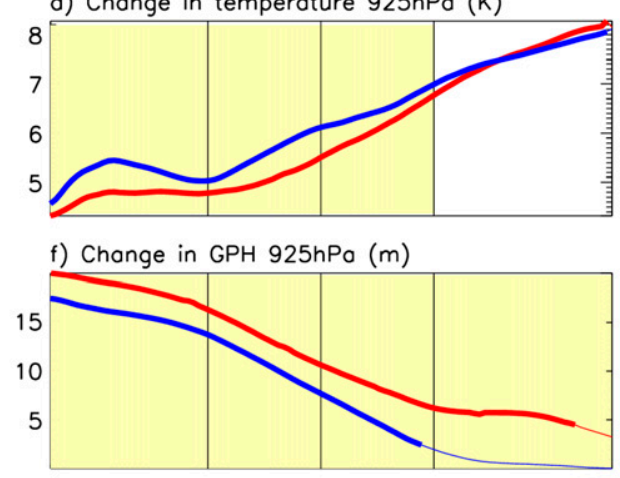

h) Change in SHL thickness $(m)$

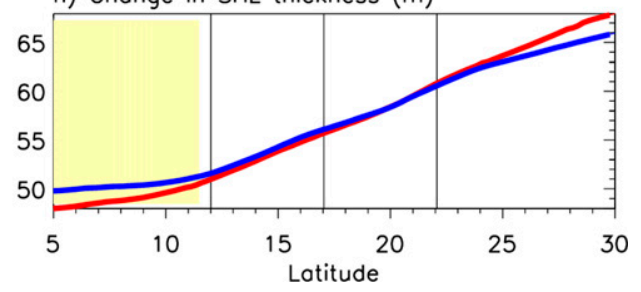

FIG. 4. July-August zonal means for (a),(b) precipitation, (c),(d) temperature, (e),(f) GPH, and (g),(h) 925-700-hPa thickness. Zonal means are averaged over longitudes $8^{\circ} \mathrm{W}-2^{\circ} \mathrm{E}$. P25 is shown by blue lines and CP4 by red lines. (left) Current climate is shown by dashed lines and future climate by solid lines. (right) Climate changes for P25 and CP4. The climate change is statistically significant where the lines are thick. The climate change in CP4 is significantly different from the climate change in $\mathrm{P} 25$ where the background is shaded yellow. Latitudes at $12^{\circ}, 17^{\circ}$, and $22^{\circ} \mathrm{N}$ are marked by vertical black lines.

in CRE on surface LW radiation is similar in both models and it opposes the increase in surface SW radiation in both models (Fig. 6b). Clear-sky surface LW radiation peaks in the north Sahel $\left(15^{\circ}-17^{\circ} \mathrm{N}\right)$ in P25 and CP4 (Fig. 6g), reflecting a balance between increasing atmospheric temperatures and decreasing humidity from south to north. Clear-sky surface LW radiation increases strongly in $\mathrm{P} 25$ and $\mathrm{CP} 4$ under climate change (Fig. 6h). This increase is the largest radiative flux response to the greenhouse gas forcing and is driven by increases in atmospheric temperatures and humidity. The increase in meridional temperature gradient under climate change (Fig. 4d) is reinforced by the greater increase in LW radiation toward the north in $\mathrm{P} 25$ and $\mathrm{CP} 4$ (Fig. 6h). There is a greater increase in meridional temperature gradient in CP4 (Fig. 4d) and this is consistent with a greater increase in humidity toward the north (Fig. 5b) and a greater increase in the meridional gradient of downwelling $\mathrm{LW}$ radiation (Fig. 6h).

Changes in CREs on surface SW and LW radiation play a role in the climate changes of P25 and CP4. Midlevel clouds over the Sahara Desert are challenging to model, and further evaluation is needed to establish whether or not such clouds are better represented in $\mathrm{CP} 4$ with its greater number of vertical levels (80) compared to P25 (63), as the findings of Mantsis et al. (2020) suggest. With different cloud schemes used in P25 and CP4, further investigations into the role of cloud changes would be warranted.

The meridional gradient in surface warming is enhanced under climate change by a positive feedback in downwelling LW radiation through the northward shift in the WAM and the associated increase in TCW over the SHL region. This can be inferred from the relationship between the change in downwelling clear-sky LW radiation and the joint distribution of TCW and its climate change (Fig. 7). The change in downwelling LW radiation is negatively correlated with TCW. Increases in downwelling LW radiation are greater at lower levels of TCW than at higher levels. This is consistent with an analysis of satellite observations that shows near-surface air temperature is most sensitive to changes in greenhouse gases in desert regions with low humidity (Wei et al. 2017). The change in downwelling LW radiation is positively correlated with the climate change in TCW. At a given level of TCW in current climate, greater increases in downwelling LW radiation under climate change are associated with 


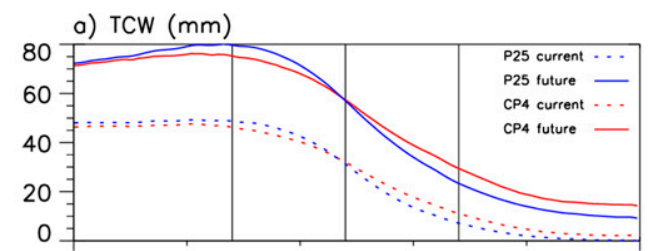

c) Specific humidity $925 \mathrm{hPa}(\mathrm{g} / \mathrm{kg})$

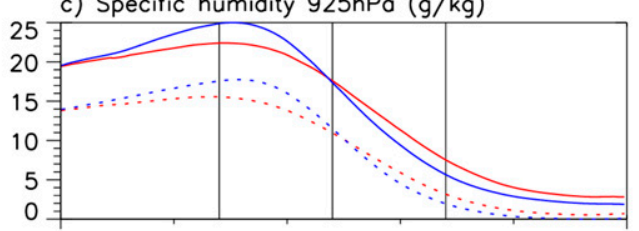

e) Meridional wind $925 \mathrm{hPa}(\mathrm{m} / \mathrm{s})$
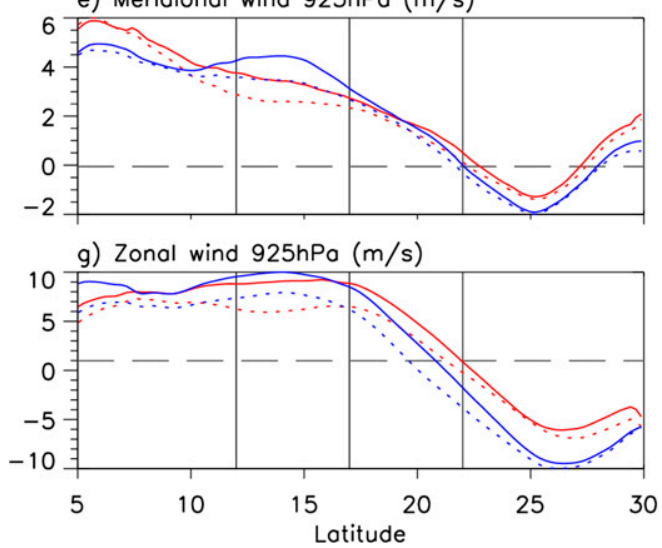

b) Change in TCW ( $\mathrm{mm})$

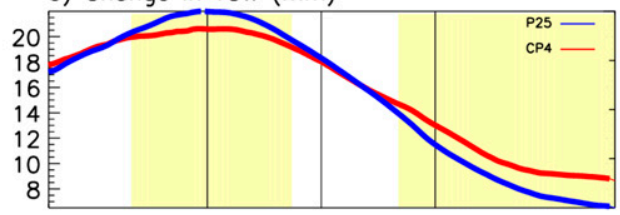

d) Change in specific humidity $925 \mathrm{hPo}(\mathrm{g} / \mathrm{kg})$
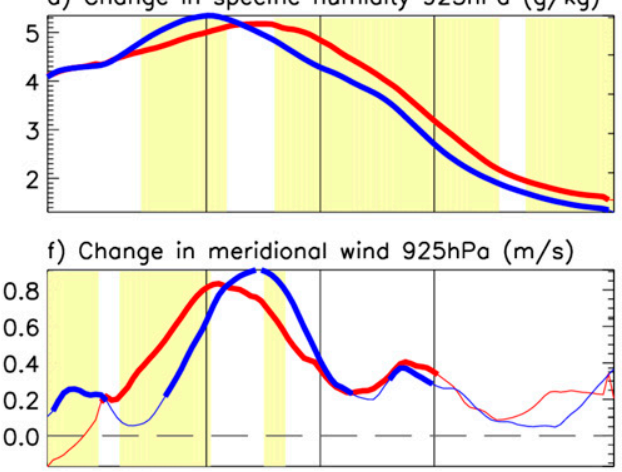

h) Change in zonal wind $925 \mathrm{hPa}(\mathrm{m} / \mathrm{s})$

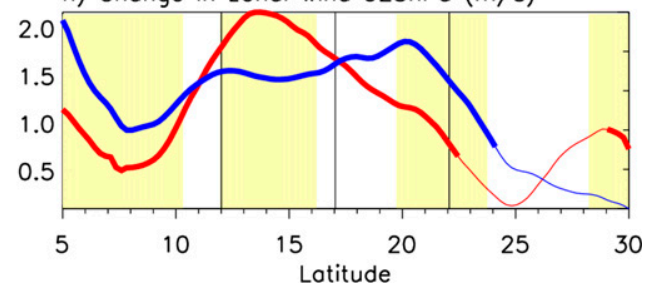

FIG. 5. July-August zonal means for (a),(b) TCW, (c),(d) specific humidity, (e),(f) meridional wind speed, and (g),(h) zonal wind speed. Zonal means are averaged over longitudes $8^{\circ} \mathrm{W}-2^{\circ} \mathrm{E}$. P 25 is shown by blue lines and CP4 by red lines. (left) Current climate is shown by dashed lines and future climate by solid lines. (right) Climate changes for P25 and CP4. The climate change is statistically significant where the lines are thick. The climate change in CP4 is significantly different from the climate change in P25 where the background is shaded yellow. Latitudes at $12^{\circ}, 17^{\circ}$, and $22^{\circ} \mathrm{N}$ are marked by vertical black lines.

greater increases in TCW. These relationships are exhibited by $\mathrm{P} 25$ and $\mathrm{CP} 4$, which is not surprising given they share the same radiation physics.

In summary, the northward shift in the WAM under climate change is reinforced by greater surface warming to the north, driven in part by the amplified meridional gradient in clear-sky LW radiation. This contributes to, and is amplified by, the increase in humidity to the north; this effect is stronger in $\mathrm{CP} 4$ than $\mathrm{P} 25$.

\section{2) LOW-LEVEL MERIDIONAL WINDS}

In this section, we examine the low-level ( $925 \mathrm{hPa})$ meridional wind speeds over central West African Sahel to explain why the wind speeds are greater in P25 than CP4 (Fig. 5e). Meridional wind speed has a near-linear relationship with the local GPH gradient in both P25 and CP4 (Fig. 8a). For a given GPH gradient, P25 has stronger meridional wind speeds than $\mathrm{CP} 4$. This shows that the stronger GPH gradient at $925 \mathrm{hPa}$ over latitudes $12^{\circ}-17^{\circ} \mathrm{N}$ in $\mathrm{P} 25$ than $\mathrm{CP} 4$ (Fig. 4e) is only partly responsible for the greater meridional wind speed. Differences in the diurnal cycle of meridional winds between P25 and $\mathrm{CP} 4$ are shown in Figs. $8 \mathrm{~b}$ and $8 \mathrm{c}$. During the afternoon, meridional winds are suppressed (Fig. 8b), likely because of strong convection in the boundary layer (Parker et al. 2005b). During the evening, there is greater acceleration of low-level winds in P25 than CP4 (Fig. 8c), which contributes to the greater the daily mean wind speeds in P25 [consistent with Marsham et al. (2013)]. Under climate change, meridional winds in P25 and CP4 change similarly and differences between them remain. In the next section, we examine the diurnal cycle of the moisture budget and show that the differences in meridional winds are likely a direct result of differences in the representation of convection (represented by the diurnal cycle in rainfall).

\section{3) MOISTURE BUdGET}

The reduced moisture in $\mathrm{CP} 4$ relative to $\mathrm{P} 25$ in the Sahel zone $\left(12^{\circ}-17^{\circ} \mathrm{N}\right)$ is consistent with weaker moist advection in CP4 (Fig. 5 shows a weaker moisture gradient and weaker winds) and stronger rainfall (Fig. 4). In this section, we analyze the diurnal cycle of the moisture budget including rainfall, surface evaporation, and moisture convergence. 

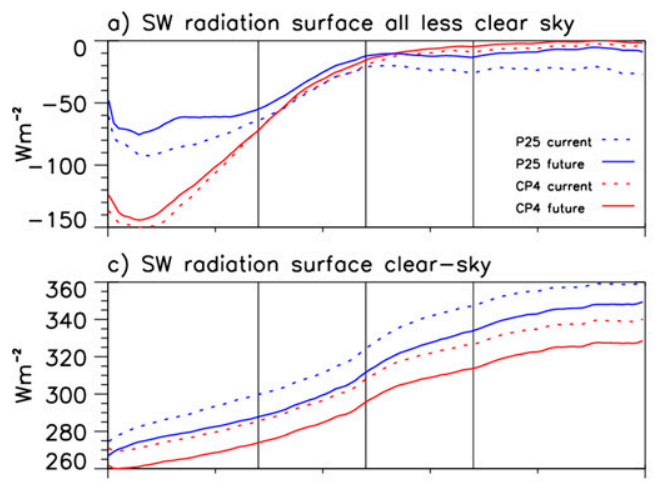

e) LW radiation surface all less clear sky
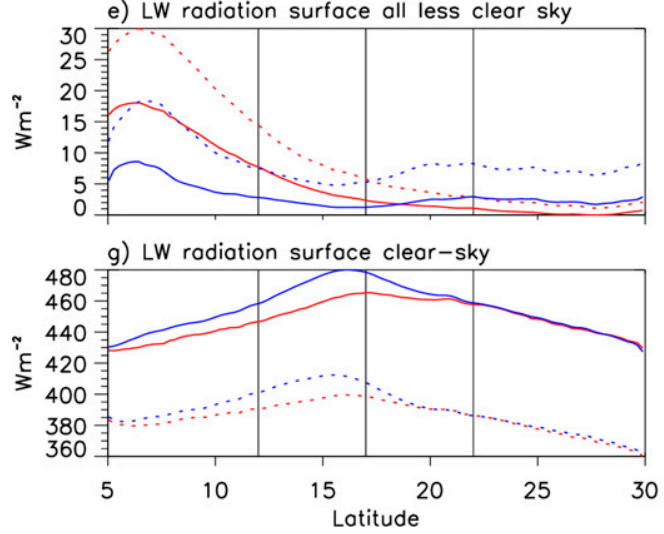
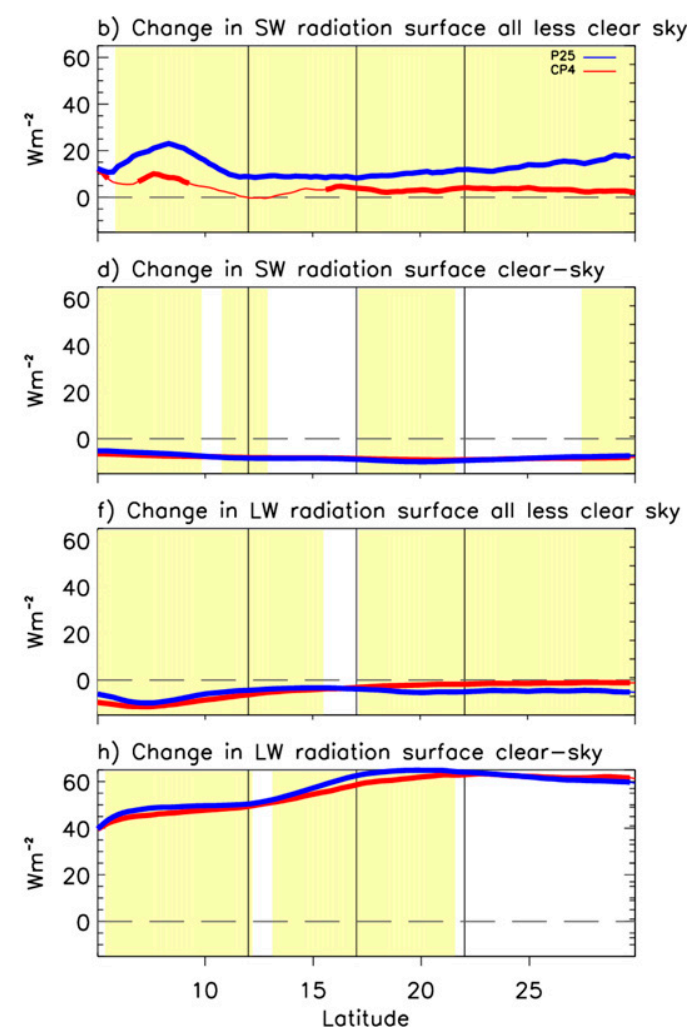

FIG. 6. July-August zonal mean downwelling radiation at the surface for: (a),(b) SW radiation (all less clear-sky), (c),(d) clear-sky SW radiation, (e),(f) LW radiation (all less clear-sky), and (g),(h) clear-sky LW radiation. Zonal means are averaged over longitudes $8^{\circ} \mathrm{W}-2^{\circ} \mathrm{E}$. P25 is shown by blue lines and CP4 by red lines. (left) Current climate is shown by dashed lines and future climate by solid lines. (right) Climate changes for P25 and CP4. The climate change is statistically significant where the lines are thick. The climate change in CP4 is significantly different from the climate change in P25 where the background is shaded yellow. Latitudes at $12^{\circ}, 17^{\circ}$, and $22^{\circ} \mathrm{N}$ are marked by vertical black lines.

In Fig. 9, we show the diurnal cycle of the atmospheric column moisture budget for the Sahel region. The diurnal cycle of rainfall in CP4 has peak rainfall later in the afternoon than P25 and rainfall is sustained through the evening and nighttime (Fig. 9a). This is consistent with previous convection-permitting studies of the diurnal cycle of rainfall in WAM (e.g., Marsham et al. 2013) and arises from explicitly resolving the physical processes of deep convection (Prein et al. 2013) and the more realistic representation of propagating storms (Prein et al. 2017; Crook et al. 2019). Under climate change, rainfall increases more strongly in CP4 than P25 (Figs. 4b and 9b). In $\mathrm{CP} 4$, the increase in rainfall occurs during the nighttime in contrast to $\mathrm{P} 25$, which has a marked increase during the afternoon. Surface evaporation decreases earlier in the afternoon in CP4 than P25, likely because of the persistence of cloud cover and rainfall (Fig. 9c). Under climate change, daytime evaporation decreases and nighttime evaporation increases in both $\mathrm{CP} 4$ and $\mathrm{P} 25$, resulting in a net increase in evaporation that is small relative the changes in rainfall and convergence (Fig. 9d).

Rainfall in CP4 persists overnight despite near-zero local convergence (Fig. 9e). The nocturnal rainfall in $\mathrm{CP} 4$ is reminiscent of observations of peak nocturnal rainfall typically associated with westward-propagating MCSs and an absence of low-level instability (Zhang et al. 2016a). CP4 has been shown to capture the dynamics and westward propagation of MCSs (Stratton et al. 2018; Crook et al. 2019). The diurnal cycles in Fig. 9 are climatologies and the near-zero convergence in $\mathrm{CP} 4$ (Fig. 9e) represents an average over times of rainy convergent conditions and dry divergent conditions.

In contrast, rainfall in P25 is prevalent in the daytime hours of peak surface temperature when convergence is positive (Fig. 9e). During the late afternoon, when parameterized convection is dying down, there is a strong decrease in rainfall in P25 despite strong moisture convergence at this time and this results in a late afternoon peak in TCW in P25 that is absent from CP4. When there is nocturnal moisture divergence in $\mathrm{P} 25$, and the surface heat fluxes are near zero, rainfall is suppressed.

Under climate change, rainfall in $\mathrm{CP} 4$ principally increases overnight fueled by increased moisture convergence and, during the morning, supported by a decrease in TCW. These changes are likely associated with the intensification of MCS 
a) P25

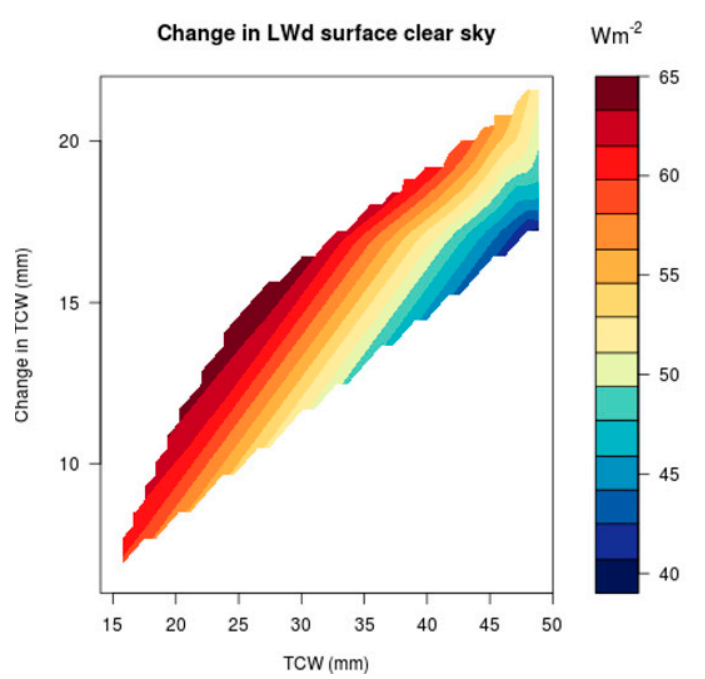

b) $\mathrm{CP} 4$

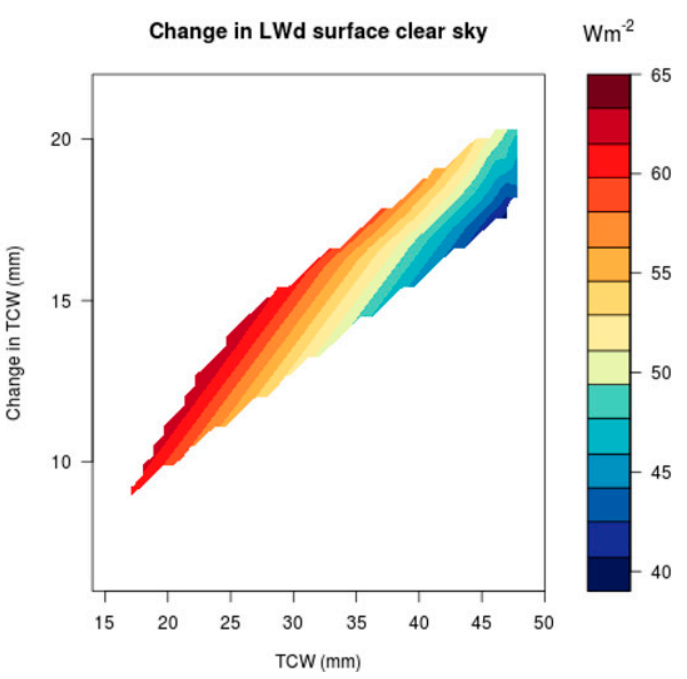

FIG. 7. The climate change in downwelling clear-sky LW radiation at the surface (colored contours) by TCW in the current climate ( $x$ axis) and climate change in TCW ( $y$ axis). The data are from the region bounded by longitudes $8^{\circ} \mathrm{W}-2^{\circ} \mathrm{E}$ and latitudes $5^{\circ}-30^{\circ} \mathrm{N}$.

dynamics in CP4 (Fitzpatrick et al. 2020). The increase in rainfall in P25 under climate change coincides with times of increased moisture convergence. During the evening and early hours of the morning after midnight, rainfall in $\mathrm{P} 25$ decreases and TCW decreases through divergence. Averaged across the diurnal cycle, the hydrological cycle intensifies more strongly under climate change in CP4 than P25. The greater increase in rainfall in $\mathrm{CP} 4$ is driven by a greater increase in convergence and evaporation changes play a minor role.

\section{4) LARGE-SCALE CIRCULATIONS}

To gain insight into the large-scale circulations we examine vertical cross sections of vertical velocity and meridional gradients in GPH in current climate (Figs. 10a,b). The vertical cross sections show a Hadley cell structure in atmospheric circulations with deep ascent within the main rain belt $\left(10^{\circ}-15^{\circ} \mathrm{N}\right)$ and subsidence to the north $\left(25^{\circ}-30^{\circ} \mathrm{N}\right)$ poleward of the regional maximum in near-surface temperature $\left(\sim 25^{\circ} \mathrm{N}\right)$. The influence of the surface temperature gradient from the Gulf of Guinea coast to the southern Sahara is apparent from the negative near-surface meridional gradients in GPH, which extend vertically to the level of the AEJ ( $~ 600$ $\mathrm{hPa})$. A similar balance is struck in future climate between the regional monsoon and the large-scale circulations (Figs. 10c,d).

In both current and future climates, explicit convection in CP4 has upscale impacts on the large-scale circulations that differ from P25 (Figs. 10a-d). Ascent in the upward branch of the Hadley cell $\left(10^{\circ}-15^{\circ} \mathrm{N}\right)$ is deeper. Subsidence in the subtropics is weaker in $\mathrm{CP} 4$, which is indicative of a weaker mean circulation (Jackson et al. 2020). In CP4, weaker subsidence immediately north of the SHL, weaker low-level ascent within the SHL $\left(20^{\circ}-25^{\circ} \mathrm{N}\right)$, and weaker gradients in low-level GPH are accompanied by the more northerly penetration of the low-level monsoon than in P25. Rainfall scales with the product of vertical velocity and TCW (Fitzpatrick et al. 2020). Intense rainfall is more strongly associated with times of high TCW in CP4 than P25 (Jackson et al. 2020). Further, for a given rate of rain intensity, greater TCW is associated with weaker vertical velocity in CP4 (Jackson et al. 2020). These relationships are much weaker in $\mathrm{P} 25$; for this reason, greater rates of vertical velocity are required in $\mathrm{P} 25$ than $\mathrm{CP} 4$ to sustain its rainfall.

Under climate change, ascent deepens in the rising branch of the Hadley cell and the rate of subsidence weakens over latitudes $25^{\circ}-30^{\circ} \mathrm{N}$ in both $\mathrm{P} 25$ and CP4 (Figs. 10e,f), which is consistent with the expected weakening of tropical atmospheric circulation under climate change (Held and Soden 2006; Chadwick et al. 2013). These changes are more pronounced in $\mathrm{CP} 4$, which also experiences weakening of mean ascent at $\sim 400 \mathrm{hPa}$ in the region of the rain belt. Under climate change, therefore, there is greater weakening of the large-scale circulation in CP4 than P25 over West Africa. This was also found for a meridional transect over central Africa (Jackson et al. 2020) and, as explained in the previous paragraph, is driven by the stronger relationships between rainfall and high TCW and between vertical velocity and TCW at given rain rates.

\section{5) LARGE-SCALE SUBSIDENCE}

We have shown that large-scale subsidence over $25^{\circ}-30^{\circ} \mathrm{N}$ is weaker in CP4 than P25 and weakens in both P25 and CP4 under climate change (Fig. 10). We have also shown that humidity is greater in $\mathrm{CP} 4$ than $\mathrm{P} 25$ over this region (Fig. 5a) and that the increase in humidity is significantly greater under 

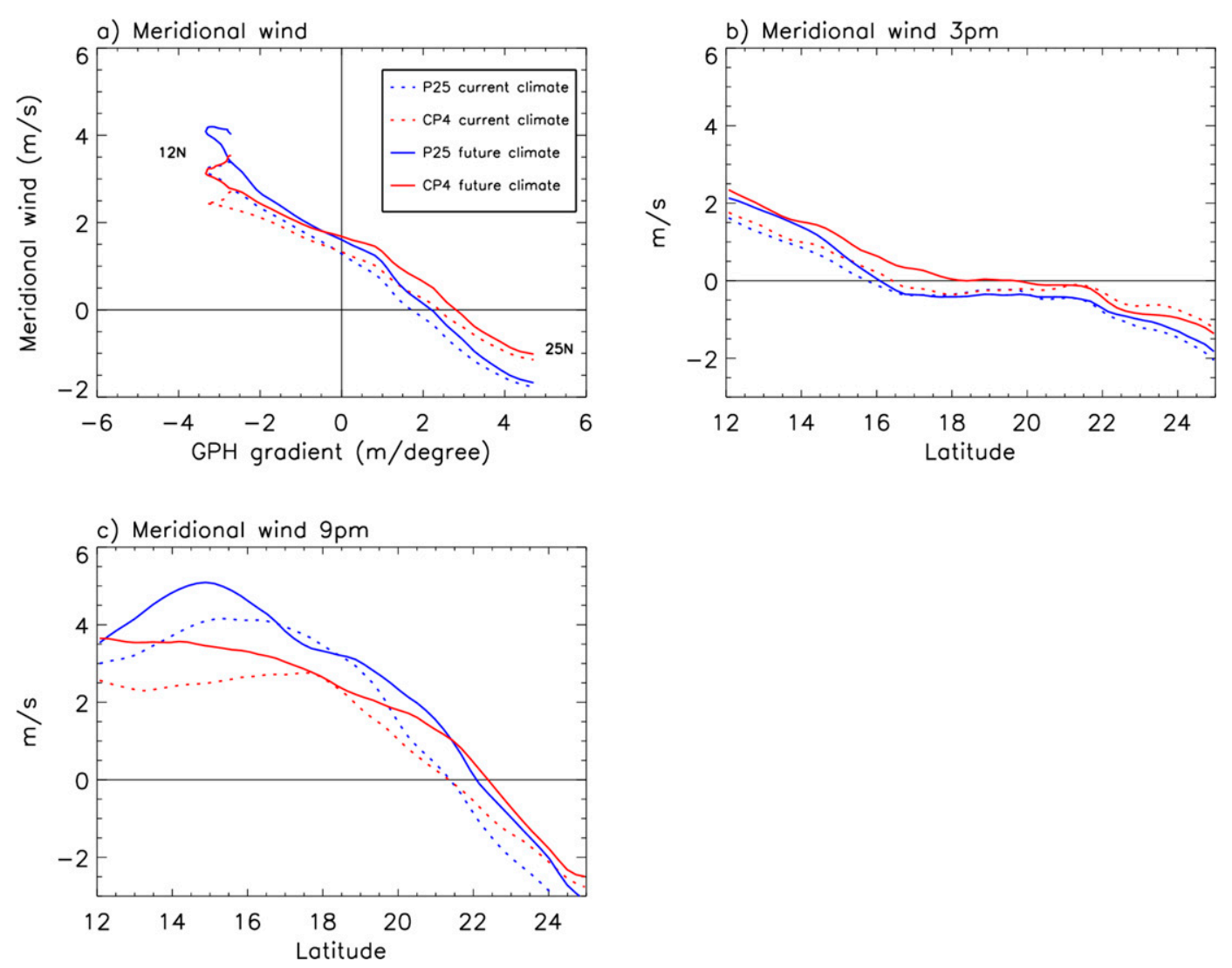

FIG. 8. (a) The relationship between daily mean local meridional gradient in GPH and daily mean meridional wind speed. (b) Meridional wind speed at 1500 local time. (c) Meridional wind speed at 2100 local time. Zonal means are averaged over longitudes $8^{\circ} \mathrm{W}-2^{\circ} \mathrm{E}$. P25 is shown by blue lines and CP4 by red lines. Current climate is shown by dashed lines and future climate by solid lines.

climate change in CP4 than P25 (Fig. 5b). In this section, we show that the more humid atmosphere over the Sahara in CP4 contributes toward its weaker large-scale circulation through attenuation of the atmospheric cooling rate.

We focus on a time of day (0600 local time) when subsidence prevails and when atmospheric heating from absorption of near-infrared solar radiation is minimal. Profiles of atmospheric heating rates are not available as model outputs so we estimate the clear-sky radiative cooling rate as shown:

$$
\omega \frac{\partial \theta}{\partial p}=\left(\frac{p_{0}}{p}\right)^{\left(R / C_{p}\right)} Q,
$$

where $\omega$ represents vertical velocity, $\theta$ potential temperature, $p$ pressure ( $p_{0}$ pressure at the reference level of $1000 \mathrm{hPa}$ ), $R$ the universal gas constant, $C_{p}$ heat capacity at constant pressure, and $Q$ the atmospheric heating rate. A balance between subsidence heating and radiative cooling of the atmosphere is assumed that should hold above the boundary layer where the diurnal cycle of each term is relatively weak.

In current climate, vertical pressure velocity is positive (which represents subsidence) between 700 and $300 \mathrm{hPa}$ and the difference between $\mathrm{P} 25$ and CP4 is statistically significant (Fig. 11a). The vertical profiles of potential temperature are similar for P25 and CP4 (Fig. 11b). The estimated atmospheric heating rates differ between the models with a weaker rate of cooling in CP4 than P25 (Fig. 11c), which is consistent with greater humidity (Fig. 11d): the differences in humidity between P25 and CP4 are small but statistically significant. Similar relationships prevail in future climate (Figs. 11e-h). While causal relationships cannot be inferred and other factors influence subsidence rates in addition to humidity, the weaker clear-sky radiative cooling rate in $\mathrm{CP} 4$ than $\mathrm{P} 25$ shows that explicit convection acts to weaken the largescale circulation through greater humidity over the Sahara region. Upscale impacts of explicit convection on largescale circulations have also been identified in CP4 over central Africa (Jackson et al. 2020) and southern Africa (Hart et al. 2018).

\section{6) WIND SHEAR}

To develop further the connection between large-scale circulations and Sahel rainfall under climate change, we examine the AEJ and meridional wind shear (Fig. 12). A vertical cross 


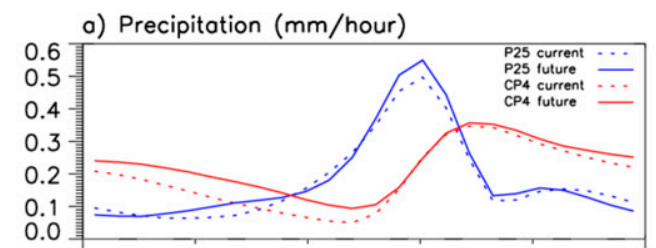

c) Evoporation ( $\mathrm{mm} / \mathrm{hour}$ )

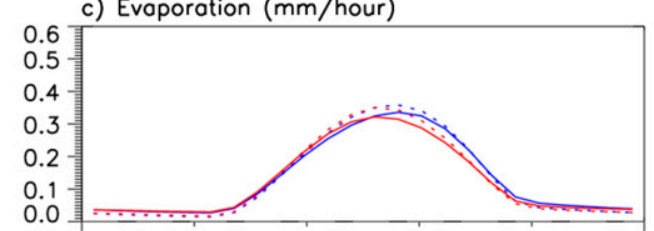

e) Convergence ( $\mathrm{mm} /$ hour)

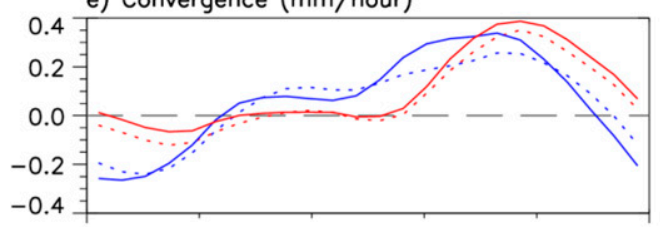

g) Chonge in TCW ( $\mathrm{mm})$

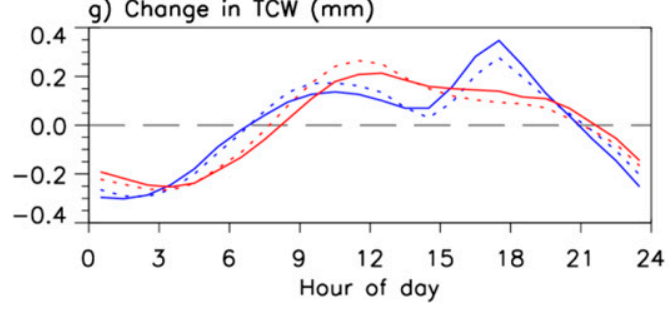

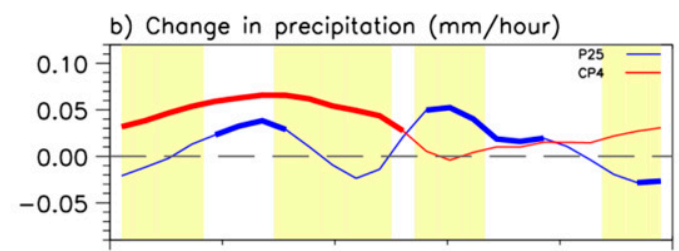
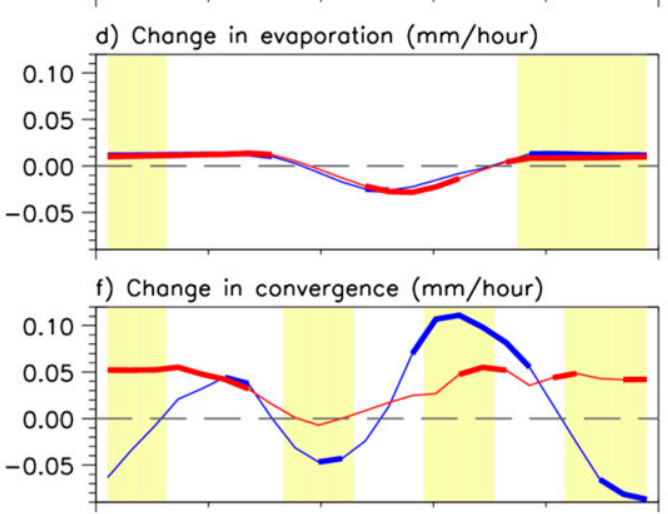

h) Change in TCW change $(\mathrm{mm})$

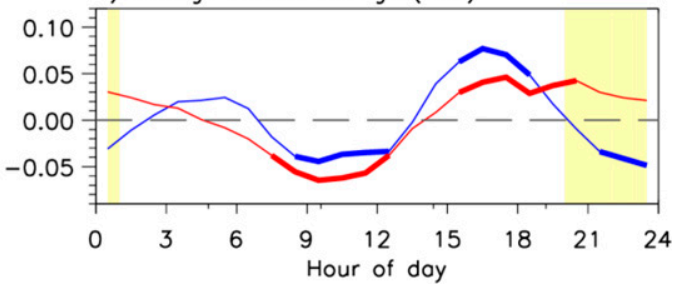

FIG. 9. July-August mean diurnal cycles for (a),(b) precipitation, (c),(d) surface evaporation, (e),(f) moisture convergence, and $(\mathrm{g}),(\mathrm{h})$ the change in TCW. Time is UTC. The means are averaged over longitudes $8^{\circ} \mathrm{W}-2^{\circ} \mathrm{E}$ and latitudes $12^{\circ}-17^{\circ} \mathrm{N}$ (the Sahel region). P25 is shown by blue lines and CP4 by red lines. (left) Current climate is shown by dashed lines and future climate by solid lines. (right) Climate changes for P25 and CP4. The climate change is statistically significant where the lines are thick. The climate change in CP4 is significantly different from the climate change in P25 where the background is shaded yellow.

section for zonal winds is provided as supplemental material (see Fig. SM1 in the online supplemental material).

Over the Sahel region, zonal winds at $600 \mathrm{hPa}$ and, by implication the AEJ, are stronger in CP4 than P25 (Fig. 12a). While the climate changes in the $600-\mathrm{hPa}$ zonal winds are not statistically significant over a large part of the Sahel, the difference between the climate changes of P25 and CP4 is significant with the zonal wind in $\mathrm{CP} 4$ strengthening in future climate relative to P25 (Fig. 12b). The strengthened zonal winds and $\mathrm{AEJ}$ in $\mathrm{CP} 4$ will contribute to increased rainfall over the Sahel region through the influence of the AEJ on the column moisture convergence over the Sahel (Cook 1999). The 600-hPa zonal winds in P25 and CP4 are near geostrophic (Fig. 12c) and their climate changes closely resemble the climate changes in the geostrophic winds (Fig. 12d). This demonstrates upscale impacts from the explicit convection in CP4 on climate changes, in this case, through modulation of meridional gradients in GPH.

Changes in wind shear under climate change also demonstrate upscale impacts from the explicit convection in CP4. Although the wind shear changes are not significant in P25 and CP4 individually, there is greater moisture convergence over the Sahel (from the surface to $800 \mathrm{hPa}$ ) under climate change in P25 and CP4 (not shown). The difference in wind shear between $\mathrm{CP} 4$ and P25 strengthens significantly and arises from strengthening of both $925-$ and $600-\mathrm{hPa}$ zonal winds (Figs. 5h and 12f respectively). Wind shear in P25 and $\mathrm{CP} 4$ closely resembles the thermal wind as do their climate changes, which are consistent with the greater increase in temperature gradient in CP4 (comparing Figs. $4 \mathrm{~d}$ and 12h). The strengthening of wind shear in $\mathrm{CP} 4$ relative to $\mathrm{P} 25$ will have a complicated relationship with the increase in rainfall. Shear is important environmental variable for the organization of MCSs (Houze 2004), although a moderate rather than strong shear environment favors the propagation of MCSs (Nicholson 2013). Shear can contribute to the development and intensification of intense MCSs (Nicholls and Mohr 2010; Taylor et al. 2017; Biasutti 2019) although, within CP4, its subsequent impact on rainfall appears to be weak (Fitzpatrick et al. 2020).

\section{Discussion and conclusions}

In this study, we used pan-Africa scale convection-permitting simulations to investigate how the mean climate of the 


\section{Vertical velocity}

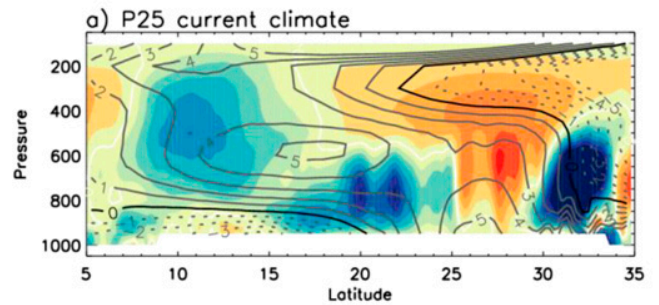

c) P25 future climate
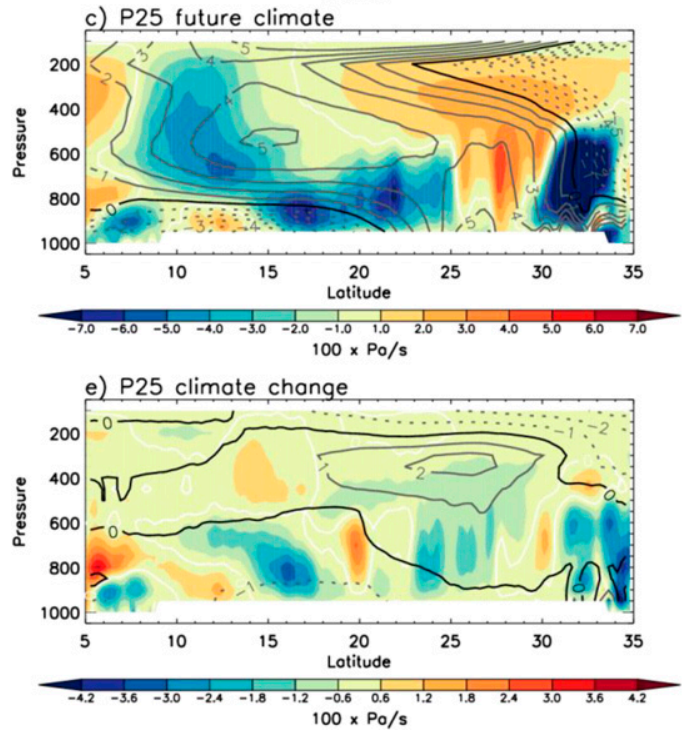

b) CP4 current climate

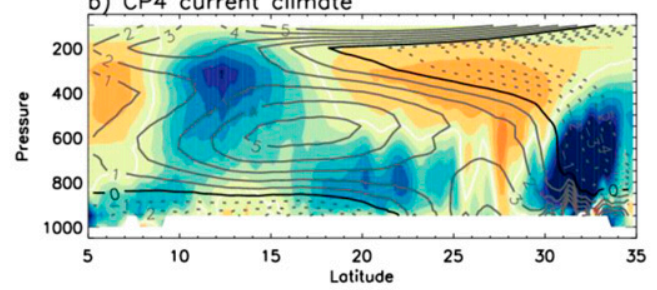

d) CP4 future climate
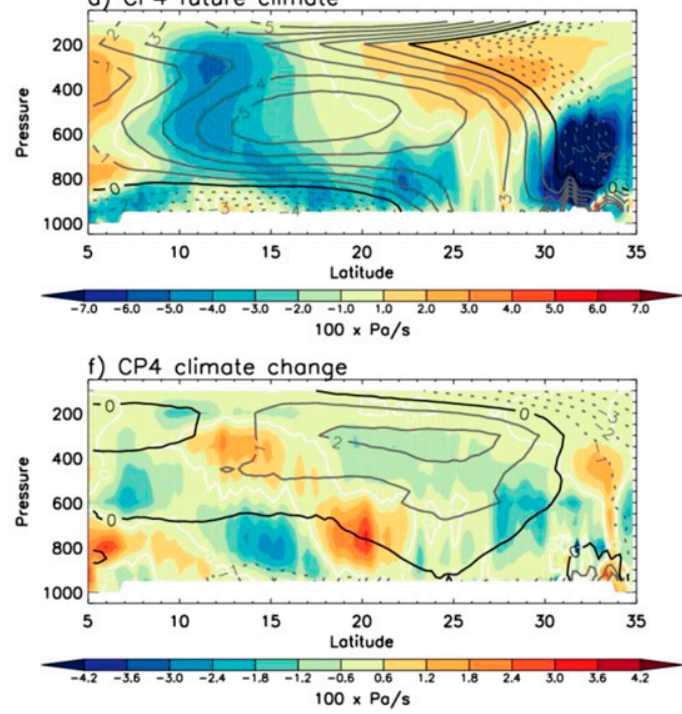

FIG. 10. Vertical cross sections of vertical velocity on atmospheric pressure levels averaged over longitudes $8^{\circ} \mathrm{W}-2^{\circ} \mathrm{E}$ (colored contours). The meridional gradient in GPH (m per degree of latitude) is superimposed with line contours. Positive gradients in GPH represent values increasing toward the north and are shown by solid lines. Negative gradients in GPH are shown by dashed lines.

central West African Sahel could change under climate change by the end of the twenty-first century. Climate changes over West Africa are, to first order, similar for P25 and CP4. The increase in temperature over West Africa exceeds $4^{\circ} \mathrm{C}$ in more than $99 \%$ of grid cells, which is analogous to RCP8.5 projections in CMIP5 (Niang et al. 2014). The P25 and CP4 simulations replicate the CMIP5 decrease in rainfall over the far western Sahel and the increase in rainfall over the northern, central, and eastern Sahel [also found in the high-resolution study of Raj et al. (2019)]. The future-climate increase in July-August Sahel rainfall in P25 and CP4 arises from a northward shift in the monsoon, a decrease in rainfall along the Guinea coast and intensification under the main rain belt. Recent observations show intensification of Sahel rainfall and a northward shift in the monsoon (Cook and Vizy 2015).

The first aim of this study is to identify the key processes that differ between parameterized and explicit convection in simulations of the current climate. The key process differences are summarized schematically in Fig. 13a. At the convective scale, there is greater rainfall in the Sahel region in $\mathrm{CP} 4$, principally occurring during the evening and maintained overnight despite near-zero column moisture-flux convergence in the period 0000-1200 UTC. The CP4 nocturnal rainfall includes more realistic organized convective systems (Crook et al. 2019) that are sustained in the absence of large-scale mean moisture convergence and therefore act to dry the column overnight. In contrast, in P25, the daily pattern of rainfall is more strongly associated with moisture convergence and occurs principally during the afternoon. In P25, increased moisture convergence yields a relatively small increase in rainfall and a relatively large increase in TCW, due to the early shutdown of convection by the parameterization scheme, so the model gains moisture during the daytime when the convection is active. These differences in diurnal cycle between $\mathrm{P} 25$ and $\mathrm{CP} 4$ reinforce findings in previous convection permitting studies that used smaller domains (e.g., Marsham et al. 2013; Birch et al. 2014b; Zhang et al. 2016b). In $\mathrm{CP} 4$, the persistence of convection into the evening also delays the acceleration of low-level winds producing all-day mean differences that are dominated by nighttime differences compared to P25 [similar to Marsham et al. (2013)]. Combined with the weaker meridional humidity gradient, the circulation differences mean that the low-level northward moisture fluxes across the Sahel are weaker in CP4 than P25. 

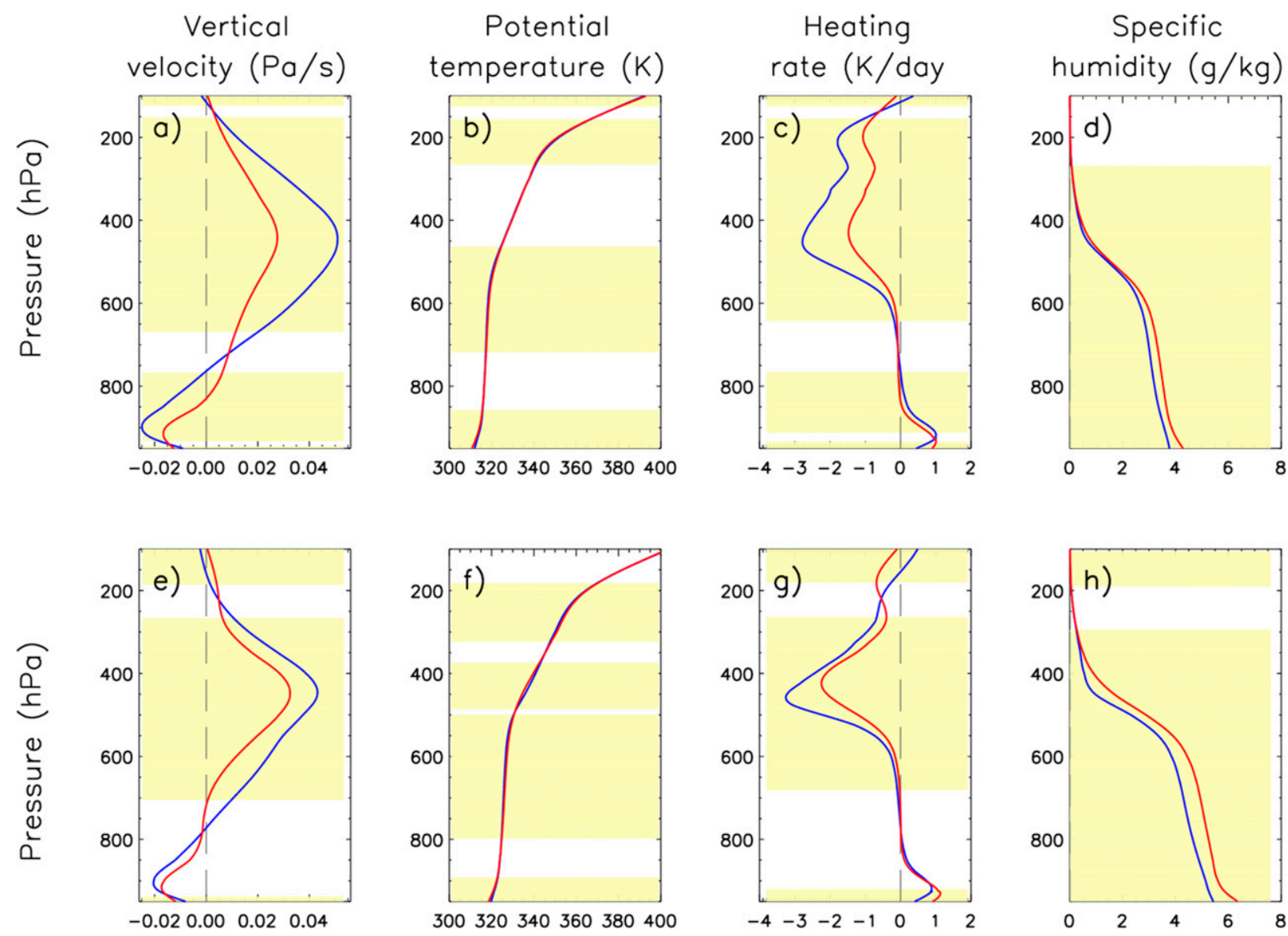

FIG. 11. July-August mean vertical profiles for (a),(e) vertical velocity, (b),(f) potential temperature, (c),(g) estimated heating rate, and (d),(h) specific humidity at 0600 local time for (top) current climate and (bottom) future climate. The means are averaged over longitudes $8^{\circ} \mathrm{W}-2^{\circ} \mathrm{E}$ and latitudes $26^{\circ}-29^{\circ} \mathrm{N}$. P25 is shown by blue lines and CP4 by red lines. CP4 is significantly different from P25 where the background is shaded yellow.

Explicit convection also drives upscale changes in the monsoon and Hadley circulations (Fig. 13a). In CP4, there is deeper ascent in the rain belt and weaker subtropical subsidence. Deeper ascent in the rain belt was also found in CP4 over central Africa (Jackson et al. 2020) and was attributed to the occurrence of intense convective updrafts, which are largely absent from P25. We have not established a causal link between the explicit convection in CP4 and its weaker subtropical subsidence. A pan-African scale analysis beyond scope of this study would be necessary to determine if it is driven by weaker large-scale Hadley circulation over Africa. We have shown, however, that the weaker subtropical subsidence in CP4 is a key component of positive water vapor feedback loop akin to the SWAT mechanism (Evan et al. 2015). Greater humidity over the Sahara in CP4 contributes to weaker atmospheric cooling rates, weaker subsidence rates, and weaker low-level pressure gradients poleward of the ITD that, in turn, support the more northerly penetration of the WAM and its flux of low-level moisture. Finally, in CP4, we note the weaker low-level ascent and weaker near-surface pressure in the region of the Sahara low. This suggests a weaker shallow meridional circulation (SMC) in CP4 than P25. A weaker SMC may contribute to the more northward penetration of the ITD and the greater Sahel rainfall in CP4 by weakening the southerly midtropospheric outflow of hot dry air from the SHL (Parker et al. 2016; Shekhar and Boos 2017).

The second aim of this study is to determine if the differences between parameterized and explicit convection persist in the future climate and to identify the key processes that differ between parameterized and explicit convection under climate change. Climate change appears to reinforce and strengthen the key differences we identified for the current climate (Fig. 13b). Differences in the diurnal cycles of rainfall, convergence, and TCW again play a key role. They drive the greater increase in rainfall and smaller increase in TCW over the Sahel in CP4 than P25. Ascent within the rain belt deepens more in CP4 than P25 and mean ascent weakens more in $\mathrm{CP} 4$. A similar response to climate change was found in CP4 over central Africa (Jackson et al. 2020) that was attributed to a much stronger 


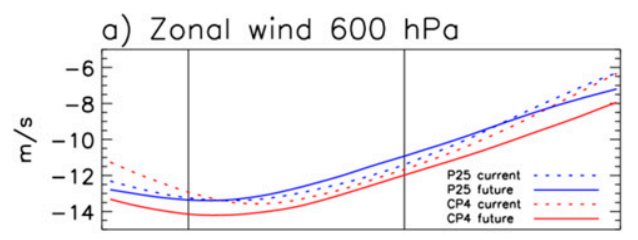

c) Geostrophic wind $600 \mathrm{hPa}$

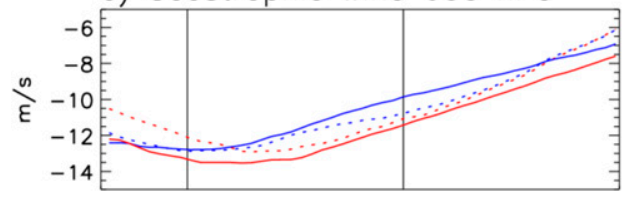

e) Wind shear
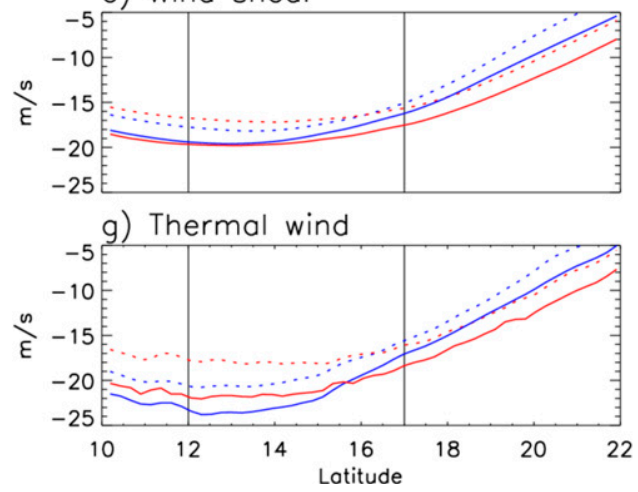

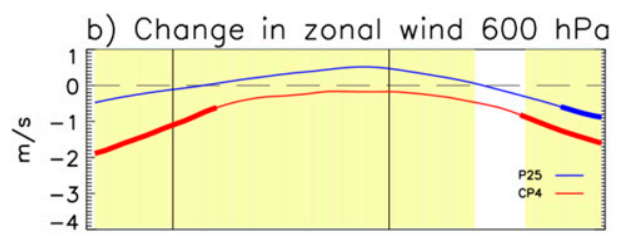

d) Change in geostrophic wind $600 \mathrm{hPa}$
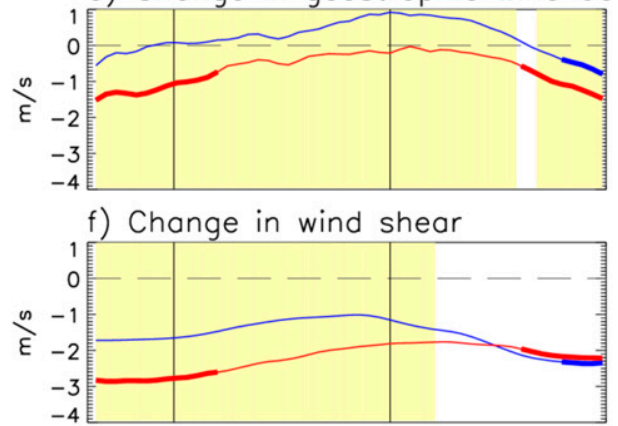

h) Change in thermal wind

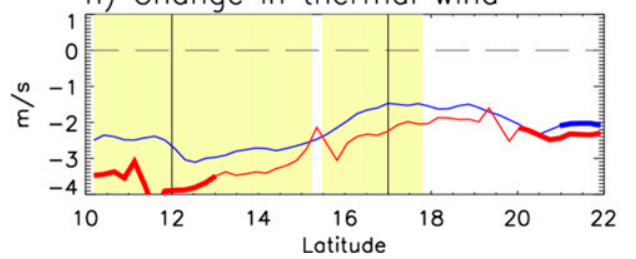

FIG. 12. July-August zonal means for (a),(b) zonal wind at $600 \mathrm{hPa}$ and (c),(d) the associated geostrophic wind, and for (e),(f) wind shear between the 925- and 600-hPa levels and (g),(h) the associated thermal wind. Zonal means are averaged over longitudes $8^{\circ} \mathrm{W}-2^{\circ} \mathrm{E}$. P25 is shown by blue lines and CP4 by red lines. (left) Current climate is shown by dashed lines and future climate by solid lines. (right) Climate changes for P25 and CP4. The climate change is statistically significant where the lines are thick. The climate change in CP4 is significantly different from the climate change in P25 where the background is shaded yellow. The Sahel region is marked by the vertical lines at latitudes of $12^{\circ}$ and $17^{\circ} \mathrm{N}$.

shift toward more intense updrafts in CP4 future climate, and weaker mean ascent was shown to be coupled with weaker subsidence. This suggests a slowdown in large-scale Hadley circulation under climate change as anticipated by Held and Soden (2006) and Chadwick et al. (2013). Finally, the greater humidity over the Sahara in $\mathrm{CP} 4$ contributes to its weaker subsidence rate and its more northerly ITD through its influence on near-surface pressure gradients.

Parameterized convection likely contributes to uncertainty in CMIP projections over West Africa. The projected increase in mean rainfall is significantly greater using explicit convection $(+6.7 \%$ in $\mathrm{P} 25$ and $+17.1 \%$ in $\mathrm{CP} 4)$ over the West African Sahel and it occurs alongside greater intensification of extreme rainfall under climate change (Kendon et al. 2019; Berthou et al. 2019a; Fitzpatrick et al. 2020). While the difference in mean rainfall change between P25 and CP4 is substantial, the range of projected changes from CMIP5 models is greater, even after elimination of models with relatively poor skill (Rowell et al. 2016). This indicates that, in addition to parameterized convection, there are other sources of uncertainty in CMIP projections. Further, to generalize our findings, more comparisons of explicit and parameterized convection under climate change using different climate models are needed. Further comparisons of explicit and parameterized convection could also shed light on systematic biases typically found in global climate models in their representation of the ITCZ (Biasutti 2019) and the SHL (Dixon et al. 2017, 2018) and advance understanding of uncertainties extant in the CMIP5 and the CMIP6 ensembles of models (Niang et al. 2014; Eyring et al. 2016). Finally, in southern West Africa MCSs and rainfall occur in distinct moist convective regimes (Maranan et al. 2018; Klein et al. 2021). It would be interesting to use the $\mathrm{CP} 4$ simulations to determine if climate change could drive future changes in convective regimes in the Sahel.

We conclude that differences between projections of the WAM from parameterized and explicit convection models are fundamentally driven by differences in the diurnal cycles of rainfall, moisture convergence, and atmospheric humidity. Further, explicit convection has upscale impacts on the location of the WAM system and the intensity of the Hadley circulation over Africa that are relevant to both current and potential future climates. This study, therefore, demonstrates the important role CPMs can play in improving the range of uncertainty in climate change 


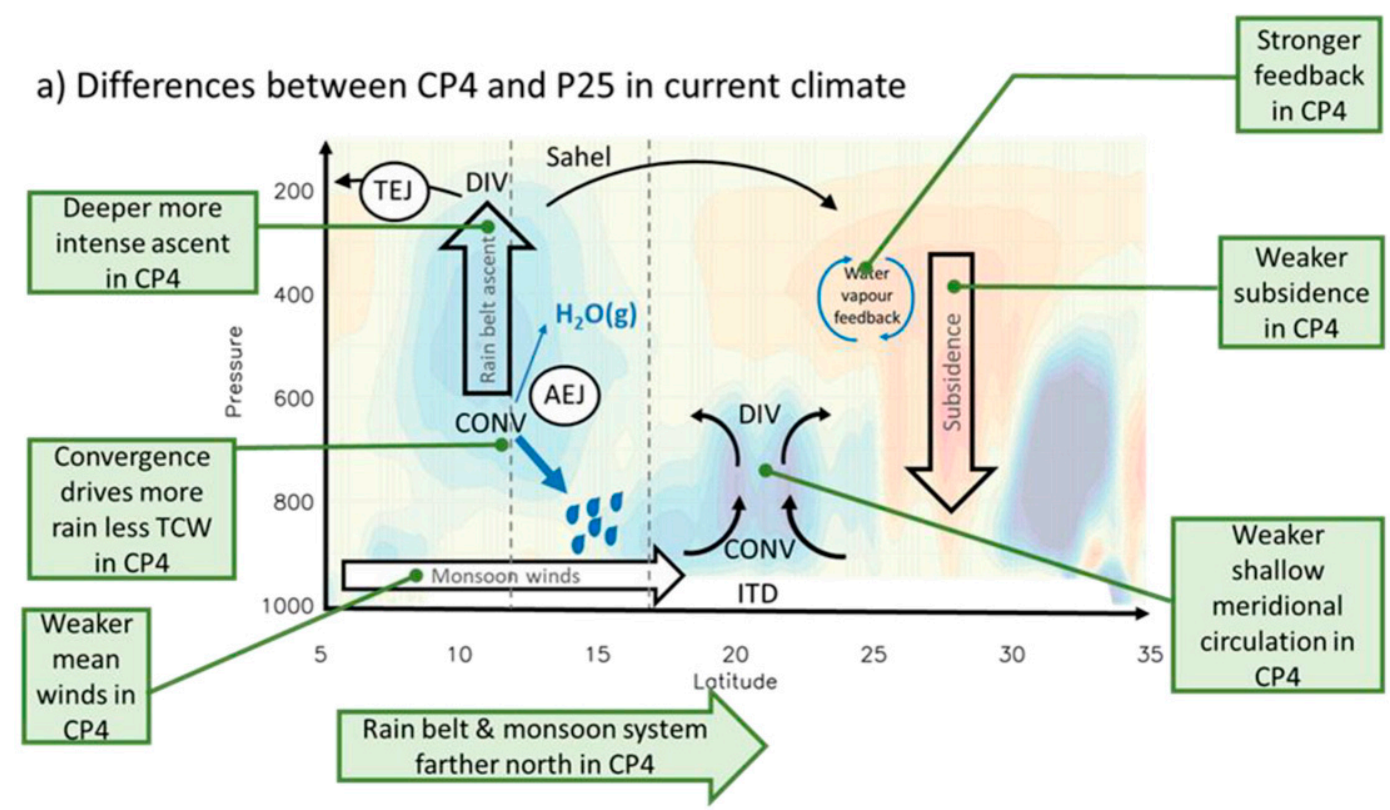

\section{b) Differences between climate changes in CP4 and P25}

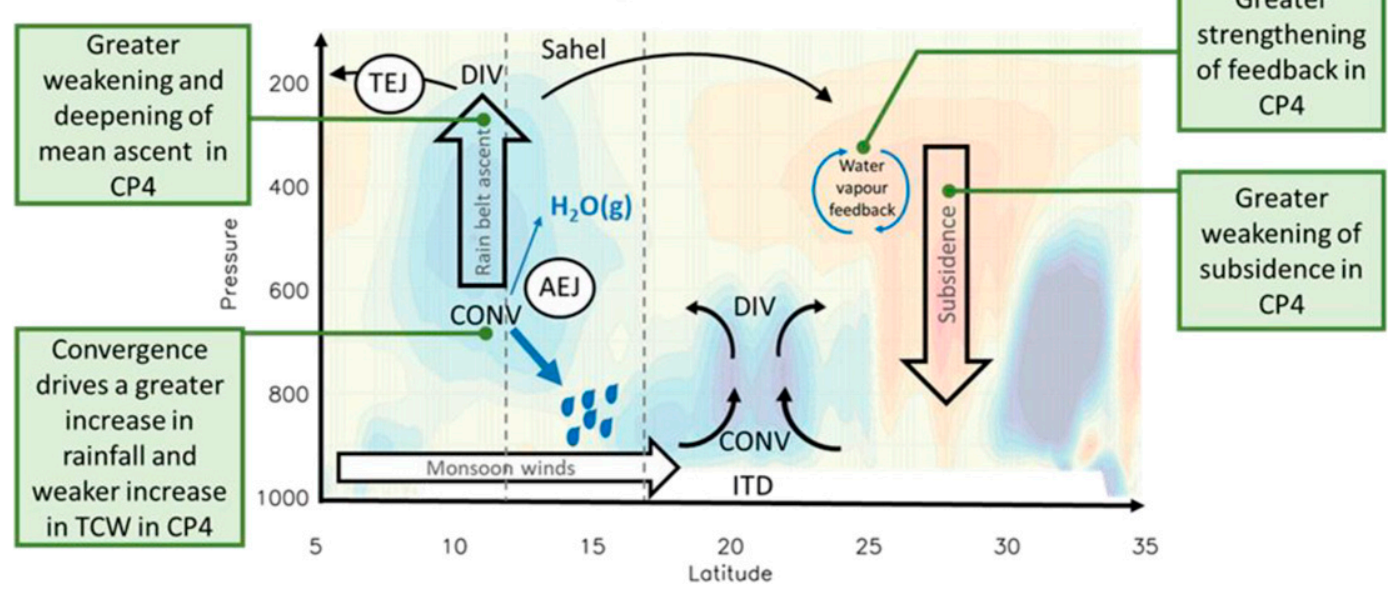

FIG. 13. Schematic diagrams showing (a) the differences in key processes between CP4 and P25 in current climate and (b) the differences in key processes between the climate changes of CP4 and P25. The shaded background represents vertical velocity with ascent represented in blue and descent in red. The black arrows represent broad atmospheric flows. Abbreviations are for intertropical discontinuity (ITD), divergence (DIV), convergence (CONV), tropical easterly jet (TEJ), and African easterly jet (AEJ).

information for model developers and climate policy decision makers.

Acknowledgments. The authors were supported by Natural Environment Research Council/Department for International Development (NERC/DFID, NE/MO17176/1, NE/ M017214/1, NE/M017265/1, and NE/M02038X/1) via the Future Climate for Africa (FCFA) funded projects: Improving Model Processes for African Climate (IMPALA) and Integrating Hydro-Climate Science into Policy Decisions for Climate-Resilient Infrastructure and Livelihoods in East
Africa (HyCRISTAL). Jackson and Marsham were supported by DACCIWA funding from the European Union Seventh Framework Programme (FP7/2007-2013) under Grant Agreement 603502 (EU project DACCIWA: Dynamicsaerosol-chemistry-cloud interactions in West Africa). Jackson was supported by the AMMA686 2050 project NE/M020126/1. Parker was supported by a Royal Society Wolfson Research Merit Award. We thank Malcolm Roberts (U.K. Met Office) for running the N512-resolution AMIP global simulation and ECMWF for the ERA-Interim dataset. The Hersbach et al. (2019) data were downloaded from the Copernicus Climate Change Service (C3S) Climate Data Store. Our results contain 
modified Copernicus Climate Change Service information from 2021. Neither the European Commission nor ECMWF is responsible for any use that may be made of the Copernicus information or data it contains. The authors wish to thank the journal editor and three anonymous reviewers for their comments which greatly improved the paper.

Data availability statement. A sample of the CP4A dataset generated under the FCFA IMPALA project is publicly available from the Centre for Environmental Data Analysis (CEDA) archive (https://data.ceda.ac.uk/badc/impala/data/).

\section{REFERENCES}

Aranami, K., T. Davies, and N. Wood, 2015: A mass restoration scheme for limited-area models with semi-Lagrangian advection. Quart. J. Roy. Meteor. Soc., 141, 1795-1803, https://doi. org/10.1002/qj.2482.

Berthou, S., E. Kendon, D. P. Rowell, M. J. Roberts, S. O. Tucker, and R. A. Stratton, 2019a: Larger future intensification of rainfall in the West African Sahel in a convection-permitting model. Geophys. Res. Lett., 46, 13 299-13307, https:// doi.org/10.1029/2019GL083544.

—, D. P. Rowell, E. J. Kendon, M. J. Roberts, R. A. Stratton, J. A. Crook, and C. Wilcox, 2019b: Improved climatological precipitation characteristics over West Africa at convectionpermitting scales. Climate Dyn., 53, 1991-2011, https://doi.org/ 10.1007/s00382-019-04759-4.

Biasutti, M., 2019: Rainfall trends in the African Sahel: Characteristics, processes, and causes. Wiley Interdiscip. Rev.: Climate Change, 10, e591, https://doi.org/10.1002/wcc.591.

- A. H. Sobel, and S. J. Camargo, 2009: The role of the Sahara low in summertime Sahel rainfall variability and change in the CMIP3 models. J. Climate, 22, 5755-5771, https://doi.org/10.1175/2009JCLI2969.1.

Bickle, M. E., J. H. Marsham, A. N. Ross, D. P. Rowell, D. J. Parker, and C. M. Taylor, 2021: Understanding mechanisms for trends in Sahelian squall lines: Roles of thermodynamics and shear. Quart. J. Roy. Meteor. Soc., 147, 983-1006, https://doi. org/10.1002/qj.3955.

Birch, C. E., J. H. Marsham, D. J. Parker, and C. M. Taylor, 2014a: The scale dependence and structure of convergence fields preceding the initiation of deep convection. Geophys. Res. Lett., 41, 4769-4776, https://doi.org/10.1002/2014GL060493.

- D. J. Parker, J. H. Marsham, D. Copsey, and L. GarciaCarreras, 2014b: A seamless assessment of the role of convection in the water cycle of the West African monsoon. J. Geophys. Res. Atmos., 119, 2890-2912, https://doi.org/10.1002/ 2013 JD020887.

Bock, O., and Coauthors, 2011: The large-scale water cycle of the West African monsoon. Atmos. Sci. Lett., 12, 51-57, https:// doi.org/10.1002/asl.288.

Boko, M., and Coauthors, 2007: Africa. Climate Change 2007: Impacts, Adaptation and Vulnerability. Cambridge University Press, 433-467.

Busby, J. W., K. H. Cook, E. K. Vizy, T. G. Smith, and M. Bekalo, 2014: Identifying hot spots of security vulnerability associated with climate change in Africa. Climatic Change, 124, 717-731, https://doi.org/10.1007/s10584-014-1142-z.

Chadwick, R., I. Boutle, and G. Martin, 2013: Spatial patterns of precipitation change in CMIP5: Why the rich do not get richer in the tropics. J. Climate, 26, 3803-3822, https://doi.org/ 10.1175/JCLI-D-12-00543.1.

Christensen, J. H., and Coauthors, 2013: Climate phenomena and their relevance for future regional climate change. Climate Change 2013: The Physical Science Basis, T. F. Stocker, Eds., Cambridge University Press, 1217-1308.

Cook, K. H., 1999: Generation of the African easterly jet and its role in determining West African precipitation. J. Climate, 12, 1165-1184, https://doi.org/10.1175/15200442(1999)012<1165:GOTAEJ > 2.0.CO;2.

- and E. K. Vizy, 2015: Detection and analysis of an amplified warming of the Sahara desert. J. Climate, 28, 6560-6580, https://doi.org/10.1175/JCLI-D-14-00230.1.

Cornforth, R., 2012: Overview of the West African monsoon 2011. Weather, 67, 59-65, https://doi.org/10.1002/wea.1896.

Crook, J. A., C. Klein, S. Folwell, C. M. Taylor, D. J. Parker, R. Stratton, and T. Stein, 2019: Assessment of the representation of West African storm lifecycles in convection-permitting simulations. Earth Space Sci., 6, 818-835, https://doi.org/10. 1029/2018EA000491.

Davies, T., 2014: Lateral boundary conditions for limited area models. Quart. J. Roy. Meteor. Soc., 140, 185-196, https://doi. org/10.1002/qj.2127.

Dee, D. P., and Coauthors, 2011: The ERA-Interim reanalysis: Configuration and performance of the data assimilation system. Quart. J. Roy. Meteor. Soc., 137, 553-597, https://doi.org/ 10.1002/qj.828.

De Kauwe, M. G., C. M. Taylor, P. P. Harris, G. P. Weedon, and R. J. Ellis, 2013: Quantifying land surface temperature variability for two Sahelian mesoscale regions during the wet season. J. Hydrometeor., 14, 1605-1619, https://doi.org/10.1175/ JHM-D-12-0141.1.

Dixon, R., A. S. Daloz, D. J. Vimont, and M. Biasutti, 2017: Saharan heat low biases in CMIP5 models. J. Climate, 30, 28672884, https://doi.org/10.1175/JCLI-D-16-0134.1.

- D. J. Vimont, and A. S. Daloz, 2018: The relationship between tropical precipitation biases and the Saharan heat low bias in CMIP5 models. Climate Dyn., 50, 3729-3744, https://doi.org/10.1007/s00382-017-3838-z.

Dosio, A., R. G. Jones, C. Jack, C. Lennard, G. Nikulin, and B. Hewitson, 2019: What can we know about future precipitation in Africa? Robustness, significance and added value of projections from a large ensemble of regional climate models. Climate Dyn., 53, 5833-5858, https://doi.org/10.1007/s00382019-04900-3.

Dudhia, J., M. W. Moncrieff, and D. W. K. So, 1987: The twodimensional dynamics of West African squall lines. Quart. J. Roy. Meteor. Soc., 113, 121-146, https://doi.org/10.1002/qj. 49711347508.

Evan, A. T., C. Flamant, C. Lavaysse, C. Kocha, and A. Saci, 2015: Water vapor-forced greenhouse warming over the Sahara desert and the recent recovery from the Sahelian drought. J. Climate, 28, 108-123, https://doi.org/10.1175/JCLID-14-00039.1.

Eyring, V., S. Bony, G. A. Meehl, C. A. Senior, B. Stevens, R. J. Stouffer, and K. E. Taylor, 2016: Overview of the Coupled Model Intercomparison Project Phase 6 (CMIP6) experimental design and organization. Geosci. Model Dev., 9, 19371958, https://doi.org/10.5194/gmd-9-1937-2016.

Field, P. R., and Coauthors, 2017: Exploring the convective grey zone with regional simulations of a cold air outbreak. Quart. J. Roy. Meteor. Soc., 143, 2537-2555, https://doi.org/10.1002/ qj.3105. 
Fink, A. H., D. G. Vincent, and V. Ermert, 2006: Rainfall types in the West African Sudanian zone during the summer monsoon 2002. Mon. Wea. Rev., 134, 2143-2164, https://doi.org/10. 1175/MWR3182.1.

Finney, D. L., J. H. Marsham, D. P. Rowell, E. J. Kendon, S. O. Tucker, R. A. Stratton, and L. S. Jackson, 2020: Effects of explicit convection on future projections of mesoscale circulations, rainfall, and rainfall extremes over eastern Africa. $J$. Climate, 33, 2701-2718, https://doi.org/10.1175/JCLI-D-190328.1.

Fitzpatrick, R. G. J., and Coauthors, 2020: What drives the intensification of mesoscale convective systems over the West African Sahel under climate change? J. Climate, 33, 31513172, https://doi.org/10.1175/JCLI-D-19-0380.1.

Fontaine, B., and N. Philippon, 2000: Seasonal evolution of boundary layer heat content in the West African monsoon from the NCEP/NCAR reanalysis (1968-1998). Int. J. Climatol., 20, 1777-1790, https://doi.org/10.1002/1097-0088(20001130) 20:14<1777::AID-JOC568>3.0.CO;2-S.

Garcia-Carreras, L., and Coauthors, 2015: The turbulent structure and diurnal growth of the Saharan atmospheric boundary layer. J. Atmos. Sci., 72, 693-713, https://doi.org/10.1175/JASD-13-0384.1.

Gregory, D., and P. R. Rowntree, 1990: A mass flux convection scheme with representation of cloud ensemble characteristics and stability-dependent closure. Mon. Wea. Rev., 118, 14831506, https://doi.org/10.1175/1520-0493(1990)118<1483: AMFCSW $>2.0 . \mathrm{CO} ; 2$.

Hart, N. C. G., R. Washington, and R. A. Stratton, 2018: Stronger local overturning in convective-permitting regional climate model improves simulation of the subtropical annual cycle. Geophys. Res. Lett., 45, 11334-11342, https://doi.org/10.1029/ 2018GL079563.

Held, I. M., and B. J. Soden, 2006: Robust responses of the hydrological cycle to global warming. J. Climate, 19, 5686-5699, https://doi.org/10.1175/JCLI3990.1.

Hersbach, H., and Coauthors, 2019: ERA5 monthly averaged data on single levels from 1979 to present. Copernicus Climate Change Service (C3S) Climate Data Store (CDS), accessed 17 August 2021, https://doi.org/10.24381/cds.f17050d7.

Houze, R. A., 2004: Mesoscale convective systems. Rev. Geophys., 42, RG4003, https://doi.org/10.1029/2004RG000150.

Jackson, B., S. E. Nicholson, and D. Klotter, 2009: Mesoscale convective systems over western equatorial Africa and their relationship to large-scale circulation. Mon. Wea. Rev., 137, 1272-1294, https://doi.org/10.1175/2008MWR2525.1.

Jackson, L. S., D. L. Finney, E. J. Kendon, J. H. Marsham, D. J. Parker, R. A. Stratton, L. Tomassini, and S. Tucker, 2020: The effect of explicit convection on couplings between rainfall, humidity, and ascent over Africa under climate change. J. Climate, 33, 8315-8337, https://doi.org/10.1175/JCLI-D-190322.1.

Johnson, R. H., 2003: Thermal low. Encyclopedia of Atmospheric Sciences, Academic Press, 2269-2273.

Kendon, E. J., R. A. Stratton, S. Tucker, J. H. Marsham, S. Berthou, D. P. Rowell, and C. A. Senior, 2019: Enhanced future changes in wet and dry extremes over Africa at convectionpermitting scale. Nat. Commun., 10, 1794, https://doi.org/10. 1038/s41467-019-09776-9.

Klein, C., F. Nkrumah, C. M. Taylor, and E. A. Adefisan, 2021: Seasonality and trends of drivers of mesoscale convective systems in southern West Africa. J. Climate, 34, 71-87, https:// doi.org/10.1175/JCLI-D-20-0194.1.
Lavaysse, C., C. Flamant, S. Janicot, D. J. Parker, J.-P. Lafore, B. Sultan, and J. Pelo, 2009: Seasonal evolution of the West African heat low: A climatological perspective. Climate Dyn., 33, 313-330, https://doi.org/10.1007/s00382-009-0553-4.

Lock, A. P., A. R. Brown, M. R. Bush, G. M. Martin, and R. N. B. Smith, 2000: A new boundary layer mixing scheme. Part I: Scheme description and single-column model tests. Mon. Wea. Rev., 128, 3187-3199, https://doi.org/10.1175/15200493(2000)128<3187:ANBLMS>2.0.CO;2.

Lothon, M., F. Said, F. Louthou, and B. Campistron, 2008: Observation of the diurnal cycle in the low troposphere of West Africa. Mon. Wea. Rev., 136, 3477-3500, https://doi.org/10. 1175/2008MWR2427.1.

Mantsis, D. F., S. Sherwood, V. Dixit, H. Morrison, and G. Thompson, 2020: Mid-level clouds over the Sahara in a convection-permitting regional model. Climate Dyn., 54, 34253439, https://doi.org/10.1007/s00382-020-05188-4.

Maranan, M., A. H. Fink, and P. Knippertz, 2018: Rainfall types over southern West Africa: Objective identification, climatology and synoptic environment. Quart. J. Roy. Meteor. Soc., 144, 1628-1648, https://doi.org/10.1002/qj.3345.

Marsham, J. H., N. S. Dixon, L. Garcia-Carreras, G. M. S. Lister, D. J. Parker, P. Knippertz, and C. E. Birch, 2013: The role of moist convection in the West African monsoon system: Insights from continental-scale convection-permitting simulations. Geophys. Res. Lett., 40, 1843-1849, https://doi.org/10. 1002/grl.50347.

— D. J. Parker, M. C. Todd, J. R. Banks, H. E. Brindley, L. Garcia-Carreras, A. J. Roberts, and C. L. Ryder, 2016: The contrasting roles of water and dust in controlling daily variations in radiative heating of the summertime Saharan heat low. Atmos. Chem. Phys., 16, 3563-3575, https://doi.org/10. 5194/acp-16-3563-2016.

Mohr, K. I., and C. D. Thorncroft, 2006: Intense convective systems in West Africa and their relationship to the African easterly jet. Quart. J. Roy. Meteor. Soc., 132, 163-176, https:// doi.org/10.1256/qj.05.55.

Moss, R. H., and Coauthors, 2010: The next generation of scenarios for climate change research and assessment. Nature, $\mathbf{4 6 3}$, 747-756, https://doi.org/10.1038/nature08823.

Niang, I., O. C. Ruppel, M. A. Abdrabo, A. Essel, C. Lennard, J. Padgham, and P. Urquhart, 2014: Africa. Climate Change 2014: Impacts, Adaptation, and Vulnerability, V. R. Barros, Eds., Cambridge University Press, 1199-1265.

Nicholls, S. D., and K. I. Mohr, 2010: An analysis of the environments of intense convective systems in West Africa in 2003. Mon. Wea. Rev., 138, 3721-3739, https://doi.org/10.1175/ 2010MWR3321.1.

Nicholson, S. E., 2009: A revised picture of the structure of the "monsoon" and land ITCZ over West Africa. Climate Dyn., 32, 7-8, 1155-1171, https://doi.org/10.1007/s00382-008-0514-3. , 2013: The West African Sahel: A review of recent studies on the rainfall regime and its interannual variability. ISRN Meteor., 2013, 453521, https://doi.org/10.1155/2013/453521.

Parker, D. J., C. D. Thorncroft, R. R. Burton, and A. DiongueNiang, 2005a: Analysis of the African easterly jet, using aircraft observations from the JET2000 experiment. Quart. J. Roy. Meteor. Soc., 131, 1461-1482, https://doi.org/10.1256/qj. 03.189.

, and Coauthors, 2005b: The diurnal cycle of the West African monsoon circulation. Quart. J. Roy. Meteor. Soc., 131, 2839-2860, https://doi.org/10.1256/qj.04.52. 
—, P. Willetts, C. Birch, A. G. Turner, J. H. Marsham, C. M. Taylor, S. Kolusu, and G. M. Martin, 2016: The interaction of moist convection and mid-level dry air in the advance of the onset of the Indian monsoon. Quart. J. Roy. Meteor. Soc., 142, 2256-2272, https://doi.org/10.1002/qj.2815.

Pearson, K. J., R. J. Hogan, R. P. Allan, G. M. S. Lister, and C. E. Holloway, 2010: Evaluation of the model representation of the evolution of convective systems using satellite observations of outgoing longwave radiation. J. Geophys. Res., 115, D20206, https://doi.org/10.1029/2010JD014265.

—, G. M. S. Lister, C. E. Birch, R. P. Allan, R. J. Hogan, and S. J. Woolnough, 2014: Modelling the diurnal cycle of tropical convection across the 'grey zone'. Quart. J. Roy. Meteor. Soc., 140, 491-499, https://doi.org/10.1002/qj.2145.

Prein, A. F., A. Gobiet, M. Suklitsch, M. H. Truhetz, N. K. Awan, K. Keuler, and G. Georgievski, 2013: Added value of convection permitting seasonal simulations. Climate Dyn., 41, 26552677, https://doi.org/10.1007/s00382-013-1744-6.

— , and Coauthors, 2015: A review on regional convection-permitting climate modeling: Demonstrations, prospects, and challenges. Rev. Geophys., 53, 323-361, https://doi.org/10.1002/ 2014RG000475.

—, R. Rasmussen, and G. Stephens, 2017: Challenges and advances in convection-permitting climate modelling. Bull. Amer. Meteor. Soc., 98, 1027-1030, https://doi.org/10.1175/ BAMS-D-16-0263.1.

Provod, M., J. H. Marsham, D. J. Parker, and C. E. Birch, 2016: A characterization of cold pools in the West African Sahel. Mon. Wea. Rev., 144, 1923-1934, https://doi.org/10.1175/ MWR-D-15-0023.1.

Raj, J., H. K. Bangalath, and G. Stenchikov, 2019: West African monsoon: Current state and future projections in a high-resolution AGCM. Climate Dyn., 52, 6441-6461, https://doi.org/ 10.1007/s00382-018-4522-7.

Reynolds, R. W., T. M. Smith, C. Liu, D. B. Chelton, K. S. Casey, and M. G. Schlax, 2007: Daily high-resolution-blended analyses for sea surface temperature. J. Climate, 20, 5473-5496, https://doi.org/10.1175/2007JCLI1824.1.

Rowell, D. P., 2003: The impact of Mediterranean SSTs on the Sahelian rainfall season. J. Climate, 16, 849-862, https://doi. org/10.1175/1520-0442(2003)016<0849:TIOMSO>2.0.CO;2.

- C. A. Senior, M. Vellinga, and R. J. Graham, 2016: Can climate projection uncertainty be constrained over Africa using metrics of contemporary performance? Climatic Change, 134, 621-633, https://doi.org/10.1007/s10584-015-1554-4.

—, R. G. J. Fitzpatrick, L. S. Jackson, and G. Redmond, 2021: Understanding intermodel variability in future projections of a Sahelian storm proxy and southern Saharan warming. J. Climate, 34, 509-525, https://doi.org/10.1175/JCLI-D-200382.1 .

Senior, C. A., and Coauthors, 2021: Convection-permitting regional climate change simulations for understanding future climate and informing decision-making in Africa. Bull. Amer. Meteor. Soc., 102, E1206-E1223, https://doi.org/10.1175/BAMS-D-200020.1 .

Seth, A., A. Giannini, M. Rojas, S. A. Rauscher, S. Bordoni, D. Singh, and S. J. Camargo, 2019: Monsoon responses to climate changes-Connecting past, present and future. Curr. Climate Change Rep., 5, 63-79, https://doi.org/10.1007/s40641019-00125-y.

Sheen, K., D. M. Smith, N. Dunstone, R. Eade, D. P. Rowell, and M. Vellinga, 2017: Skilful prediction of Sahel summer rainfall on inter-annual and multi-year time scales. Nat. Commun., 8 , 14966, https://doi.org/10.1038/ncomms14966.

Shekhar, R., and W. R. Boos, 2017: Weakening and shifting of the Saharan shallow meridional circulation during wet years of the West African monsoon. J. Climate, 30, 7399-7422, https://doi.org/10.1175/JCLI-D-16-0696.1.

Sherwood, S. C., S. Bony, and J.-L. Dufresne, 2014: Spread in model climate sensitivity traced to atmospheric convective mixing. Nature, 505, 37-42, https://doi.org/10.1038/nature12829.

Smith, R. N. B., 1990: A scheme for predicting layer clouds and their water content in a general circulation model. Quart. J. Roy. Meteor. Soc., 116, 435-460, https://doi.org/10.1002/qj. 49711649210.

Stein, T. H. M., and Coauthors, 2019: An evaluation of clouds and precipitation in convection-permitting forecasts for South Africa. Wea. Forecasting, 34, 233-254, https://doi.org/10.1175/ WAF-D-18-0080.1.

Stratton, R., and Coauthors, 2018: A pan-Africa convection-permitting regional climate simulation with the Met Office Unified Model: CP4-Africa. J. Climate, 31, 3485-3508, https://doi. org/10.1175/JCLI-D-17-0503.1.

Taylor, C. M., C. E. Birch, D. J. Parker, N. Dixon, F. Guichard, G. Nikulin, and G. M. S. Lister, 2013: Modeling soil moistureprecipitation feedback in the Sahel: Importance of spatial scale versus convective parameterisation. Geophys. Res. Lett., 40, 6213-6218, https://doi.org/10.1002/2013GL058511. , and Coauthors, 2017: Frequency of extreme Sahelian storms tripled since 1982 in satellite observations. Nature, 544, 475478, https://doi.org/10.1038/nature22069.

Thorncroft, C. D., H. Nguyen, C. Zhang, and P. Peyrillé, 2011: Annual cycle of the West African monsoon: Regional circulations and associated water vapour transport. Quart. J. Roy. Meteor. Soc., 137, 129-147, https://doi.org/10.1002/qj.728.

Trzeciak, T. M., L. Garcia-Carreras, and J. H. Marsham, 2017: Cross-Saharan transport of water vapor via recycled cold pool outflows from moist convection. Geophys. Res. Lett., 44, 1554-1563, https://doi.org/10.1002/2016GL072108.

Vizy, E. K., and K. H. Cook, 2018: Mesoscale convective systems and nocturnal rainfall over the West African Sahel: Role of the inter-tropical front. Climate Dyn., 50, 587-614, https://doi. org/10.1007/s00382-017-3628-7.

- , and - 2019: Understanding the summertime diurnal cycle of precipitation over sub-Saharan West Africa: Regions with daytime rainfall peaks in the absence of significant topographic features. Climate Dyn., 52, 2903-2922, https://doi.org/ 10.1007/s00382-018-4315-z.

,-- J. Cretat, and N. Neupane, 2013: Projections of a wetter Sahel in the twenty-first century from global and regional models. J. Climate, 26, 4664-4687, https://doi.org/10.1175/ JCLI-D-12-00533.1.

Walters, D. N., and Coauthors, 2017: The Met Office Unified Model Global Atmosphere 6.0/6.1 and JULES Global Land 6.0/6.1 configurations. Geosci. Model Dev., 10, 1487-1520, https://doi.org/10.5194/gmd-10-1487-2017.

— Atmosphere 7.0/7.1 and JULES Global Land 7.0 configurations. Geosci. Model Dev., 12, 1909-1963, https://doi.org/10. 5194/gmd-2017-291.

Wei, N., L. Zhou, Y. Dai, G. Xia, and W. Hua, 2017: Observational evidence for desert amplification using multiple satellite datasets. Sci. Rep., 7, 2043, https://doi.org/10.1038/s41598017-02064-w. 
Wilson, D. R., A. C. Bushell, A. M. Kerr-Munslow, J. D. Price, and C. J. Morcrette, 2008: PC2: A prognostic cloud fraction and condensation scheme. I: Scheme description. Quart. J. Roy. Meteor. Soc., 134, 2093-2107, https://doi.org/10.1002/qj. 333.

Wood, N., and Coauthors, 2014: An inherently mass-conserving semi-implicit semi-Lagrangian discretization of the deepatmosphere global non-hydrostatic equations. Quart. J. Roy. Meteor. Soc., 140, 1505-1520, https://doi.org/10.1002/qj.2235.

Woodhams, B. J., C. E. Birch, J. H. Marsham, C. L. Bain, N. M. Roberts, and D. F. A. Boyd, 2018: What is the added value of a convection-permitting model for forecasting extreme rainfall over tropical East Africa? Mon. Wea. Rev., 146, 2757-2780, https://doi.org/10.1175/MWR-D-17-0396.1.

Zhang, G., K. H. Cook, and E. K. Vizy, 2016a: The diurnal cycle of warm season rainfall over West Africa. Part I:
Observational analysis. J. Climate, 29, 8423-8437, https://doi. org/10.1175/JCLI-D-15-0874.1.

,-- , and,$- 2016 \mathrm{~b}$ : The diurnal cycle of warm season rainfall over West Africa. Part II: Convection-permitting simulations. J. Climate, 29, 8439-8454, https://doi.org/10.1175/ JCLI-D-15-0875.1.

Zhou, L., 2016: Desert amplification in a warming climate. Sci. Rep., 6, 31065, https://doi.org/10.1038/srep31065.

- , H. Chen, and Y. Dai, 2015: Stronger warming amplification over drier ecoregions observed since 1979. Environ. Res. Lett., 10, 064012, https://doi.org/10.1088/1748-9326/10/6/064012.

Zipser, E. J., D. J. Cecil, C. Liu, S. W. Nesbitt, and D. P. Yorty, 2006: Where are the most intense thunderstorms on Earth? Bull. Amer. Meteor. Soc., 87, 1057-1071, https://doi.org/10. 1175/BAMS-87-8-1057. 